\title{
Moving to Opportunity or Isolation? Network Effects of a Slum Relocation Program in India
}

\author{
Sharon Barnhardt, Erica Field and Rohini Pande*
}

August 15, 2014

\begin{abstract}
A housing lottery in a large Indian city provided 110 out of 497 participants the opportunity to move out of a slum and into improved housing on the city's periphery. Fourteen years after housing assignment, relative to lottery losers, winners report better housing conditions farther from the city center, but no change in family income or human capital. Winners also state increased isolation from family and caste networks and lower access to informal insurance. In particular, they are significantly less likely to know someone they can rely on for borrowing needs and report fewer informal transfers in the event of shocks. We also observe significant program exit: $34 \%$ of winners never even moved into the assigned housing and $32 \%$ eventually exited the colony to be closer to family and the city center. Our results suggest that the benefits of improved suburban housing were offset by its drawbacks in the form of destruction of social capital, pointing to the importance of considering social networks when designing housing programs for the poor.
\end{abstract}

${ }^{*}$ The authors are from the Indian Institute of Management - Ahmedabad, Duke University, and Harvard University. For financial and field support, we thank the National Science Foundation (grant SES-0752792), The US Department of Labor ILAB (DOL ILAB), the Centre for Microfinance (CMF) at IFMR, the MossavarRahmani Center for Business and Government, the Real Estate Academic Initiative at Harvard University and the Exxon Mobil Foundation under the Closing the Global Gender Gap Initiative in Economic Participation (hosted by the Women and Public Policy Program at Harvard University). We thank Susanna Berkouwer, Sarah Bishop, Manasee Desai, Janaki Kibe, Keshubhai, Marie-Pascale Grimon, Vanya Pasheva, and Divya Varma for excellent research assistance, Avdhut Fadanwis and Sachin Srivastava for data management, and DOL ILAB staff for detailed comments on an earlier draft. All errors are our own. 


\section{Introduction}

Nearly a billion people live in urban slums in the developing world, places that fail to provide inhabitants adequate physical infrastructure (UN High Commissioner for Refugees, 2010). ${ }^{1}$ The high population density and confined quarters have caused widespread concern that urban slums breed crime and disease, and are therefore not way-stations on the road to better living, but rather poverty traps (Marx et al., 2013).

A common policy response has been to relocate slum dwellers to improved housing on city peripheries (U.N. Habitat, 2003; Warah, 2004). Suburban housing projects offer the benefits of residential improvements and cleaner, safer environs, yet they also entail the loss of the major advantages of urbanicity, including access to public services, short and affordable commutes, and proximity to ethnic enclaves (Lall et al., 2008). Given these tradeoffs, an open question is whether housing relocation programs actually benefit those they are intended to serve. Even though most are provided on a voluntary basis, the net benefits of relocating may be close to zero, implying low social returns to public spending on such programs. And since slum dwellers have little opportunity to experiment with suburban living, it is not obvious that those who sign up for housing programs are even made weakly better off by moving.

To date, the value of urban relocation programs for slum dwellers remains largely untested mainly because of the difficulty of addressing selection concerns inherent to comparing individuals residing in different locations (Field and Kremer, 2006; Bayer et al., 2008). Specifically, those who anticipate particularly high benefits or very low costs of relocation are likely to be over-represented among households that opt for a suburban housing program (Marx et al., 2013). In such cases, observing better socio-economic outcomes among movers relative to those who remain in slums obfuscates the causal impact of relocation to peripheral housing.

In this paper, we examine a housing program that assigned housing units to slum-dwellers in India randomly via a lottery. This assignment rule provided a rare source of exogenous variation in the residential location of slum dwellers akin to the Moving to Opportunity (MTO) experiment in the U.S. A second advantage is the ability to evaluate relatively long-run program

$\overline{1}$ By definition, a slum household lacks one or more of: secure tenure, durable housing, a sufficient living area of two persons or less per room, access to safe water, and access to sanitation (U.N. Habitat, 2003) 
effects: 14 years after housing units were assigned, we successfully tracked and interviewed $89 \%$ of original lottery applicants.

This unique experimental opportunity was afforded by a housing mobility program organized by the Self Employed Women's Association (SEWA), a leading trade union for poor women in India, in partnership with the local government of Ahmedabad, the capital city of the Indian state of Gujarat. The 497 program participants drawn from city slums were all piece-rate workers who made unfiltered cigarettes, or beedis, an important group of unionized, informalsector workers. ${ }^{2}$ Lottery winners received the opportunity to move into improved housing in a neighborhood on the city's periphery (from now on, Colony A), roughly 7.5 miles from the center. Housing units were allocated six years after the lottery at a monthly cost well below market: the estimated subsidy per unit was more than $50 \%$ of the lease value. Although not a government scheme, the nature and value of this program are very similar to housing projects for low-income urban populations regularly offered by state and federal housing authorities of India, such as the ongoing Affordable Housing in Partnership scheme. ${ }^{3}$

Fourteen years after housing allocation, slum-dwellers who won the opportunity to relocate to objectively higher-quality housing in a safer and cleaner location were no better off on a variety of socio-economic measures than those who were not given the same opportunity to leave the slums. In particular, the economic well-being of lottery winners and losers was similar in terms of current income, labor force participation, household health, and child outcomes.

Furthermore, we observe significant program exit: One-third of winners chose not to move to Colony A. Even more surprising, a further $32 \%$ moved in but then returned to more centrally located slums within ten years, forgoing the indefinite future stream of highly subsidized rent and tenure security that public housing offers. While some of those who left Colony A recovered partial value via illegal rentals or sales of occupancy rights, by all accounts the private value of the apartment could not be fully recovered on the market since tenure security was not

$2 \quad$ Over 1.4 million women in India earn a living doing this work, making it one of the largest female, informallabor sectors (Office of the Registrar General, Census Commissioner, 2001).

3 Under the AHP scheme, the central government provides a subsidy of INR 75,000 per unit for municipal governments and partners to build large Affordable Housing Projects and offer the units at an affordable price to households with income below INR 100,000 (Ministry of Housing and Urban Poverty Alleviation, 2013). The scheme is applicable in all cities across India and aims to build up to one million units (Ministry of Housing and Urban Poverty Alleviation, 2011). 
transferable to an illegal occupant. Consistent with this, regression estimates show no difference between winners and losers in terms of housing expenditures net of revenues, suggesting that most winners simply "gave up" the program.

Much of the potential economic value of public housing programs in low-income settings arises from the government's ability to grant secure tenure to those poor people who value it most. These returns depend largely on participants abiding by lease agreements and not reverting to illegal occupancy, through which tenure security cannot be transferred or targeted appropriately. In the case of Colony A, since most winners either abandoned the unit or were delinquent on their lease agreements (or both), winners were ultimately no more likely to benefit from the greater tenure security that public housing potentially provides when the government acts as landlord.

The lack of socioeconomic improvement among winners, the high exit rate, and continued tenure insecurity all suggest that the long-run economic value of this fairly expensive public program was close to zero. ${ }^{4}$ These results are particularly stark given that lottery participants were largely responsible for organizing the housing movement, and hence represent a group of particularly motivated potential beneficiaries. Furthermore, as home-based workers, they were presumably more indifferent than most slum dwellers to residential location. Hence, our findings are arguably an upper bound on the self-targeting that a typical public housing scheme can hope to achieve.

So why was relocating to Colony A ultimately deemed undesirable by most participants? The only negative program effects we detect are reduced ties to participants' social networks, including family. Relative to lottery losers, winners live significantly further from their adult children and report a lower probability of seeing them on a regular basis. Moreover, they are less likely to know someone they can rely on for borrowing needs (6 to 9 percentage points less, depending on the item lent/borrowed) and have, on average, known such a person for nearly

$4 \quad$ Long-run studies of the MTO program in the U.S. also reveal no differences across program winners and losers in terms of employment levels or trends, wages, or earnings 10-15 years after assignment. However, they find that adult winners had better mental and physical health. Long-term child health was not affected overall, though the subgroup of female youth were less likely to have health problems (Ludwig et al., 2013a). Our null findings are also consistent with other public housing opportunity studies in large North American cities (Oreopolous, 2003; Jacob, 2004). 
three fewer years, which indicates that risk-sharing ties have been severed in the act of moving out of the slums. Consistent with this interpretation, in qualitative interviews, movers report that they had difficulty maintaining network links outside of Colony A. Correspondingly, they are less likely to rely on informal insurance in the event of a shock: losers, but not winners, report receiving informal transfers through their social networks in the event of a shock. Hence, geographic isolation appears to imply a significant economic as well as social cost.

The restructuring of social networks is also evident in the fact that lottery winners are no less likely to rely on neighborhood networks for borrowing and lending needs, which indicates that they have formed links with new neighbors. ${ }^{5}$ However, while slums are generally segregated into religious, linguistic and caste-based enclaves (Vithayathil and Singh, 2011; Field et al., 2008), public housing is most often a mix. As a result, within-Colony A risk-sharing arrangements were presumably weaker than those in city slums because they were newer, and involved greater sub-caste diversity.

On the flip side, relative to non-winners, winners report higher neighborhood-level collective action, suggesting that geographic isolation - or the greater network closure it implies potentially facilitated cooperation around local public goods. ${ }^{6}$ However, there appears to be a trade-off in terms of participation in city-wide public goods, specifically in the Beedi Workers' Union, which is significantly lower among winners, presumably due to greater distance to the city center.

Other potentially negative effects of relocating away from the city center such as higher commuting costs were insignificant because participants all worked at home and Colony A's distance from school and health clinics was not extreme. Hence, we interpret program exit in our setting as reflective of the socio-economic costs of reducing contact with existing network members. Qualitative interviews support the interpretation that several of those who moved into Colony A but eventually left did so because the isolation proved too costly.

Ours is the first experimental evaluation of a slum relocation program in a developing country, and we also present the first long-run experimental analysis of geographic isolation on risk-

$5 \quad$ As shown in a number of studies, network ties are typically strongest within neighborhoods (Festinger et al., 1963; Abu-Ghazzeh, 1999; Sacerdote and Marmaros, 2006).

6 Greater network closure implies a network of strongly interconnected elements (Coleman, 1988, 1990). 
sharing and social insurance in any context. ${ }^{7}$ The idea that housing mobility programs change social networks is also evident in the MTO program: treatment households reported more college-educated friends and greater exposure to more affluent peers, but for youth there was a significant decline in the fraction who report at least one close friend, and male youth in the treatment group were less likely than those in the controls to see friends from their original neighborhood (Sanbonmatsu et al., 2011). ${ }^{8}$ There is no direct evidence from MTO, however, of changes in risk-sharing capacity. ${ }^{9}$

These findings contribute a new angle to a large and growing literature on the economic benefits of urbanicity (Glaeser, 2011) that is likely to be particularly important in developing country contexts, and help explain why slum relocation programs are so politically fraught.

The remainder of this paper proceeds as follows. Section 2 describes the study context, the dataset and empirical strategy. Section 3 examines the impact of the housing program on residential location and socio-economic well-being. We conclude this section with an analysis of the network costs of relocation. Section 4 concludes.

\section{Background and Data}

Our study follows the sample of slum dwellers in Ahmedabad who entered the housing lottery. Below we describe the study population and the housing program, and then our survey design and empirical strategy.

$7 \quad$ While some non-experimental papers have noted the mixed success of slum relocation programs (Viratkapan et al., 2004), much of the focus has been on commuting costs alone (Takeuchi et al., 2008). An exception is Kapoor et al. (2004), who estimate models of location choice in urban India and find significant costs from relocation in terms of disruption of religious and linguistic networks. There are few quantitative estimates of the significance of neighbor effects in developing countries. Montgomery and Hewett (2005) and Barnhardt (2009) are exceptions, but neither examine changes in the risk-sharing capacity of networks.

8 As in our study, households that moved showed greater collective efficacy: treatment households were more likely to have neighbors who would support shared social norms on neighborhood cleanliness (Ludwig et al., 2013b).

9 Studies with college housing arrangements have focused on social interactions extensively. Ward (2006) examines housing isolation, social networks and time investment choices among Harvard undergraduates and finds that students in a location farther from where campus life is centered participate the same amount, but shift to less central activities. They spend more time with local networks and in local activities, with local networks becoming denser. 


\subsection{Slum Dwellers in Ahmedabad}

With roughly 6.4 million residents, Ahmedabad is India's sixth most populous urban area and the largest city in Gujarat, one of India's fastest-growing and most industrialized states (Office of the Registrar General, Census Commissioner, 2011). Despite this growth, in early 2000s the urban poverty rate in Ahmedabad was roughly 1.4 times the Indian average at 34\% (Cities Alliance, 2002), largely due to the decline of Ahmedabad's textile industry. The economic mainstay of the city's poor remains informal sector employment, which accounted for $76.7 \%$ of employment in the city and generated 46.8\% of income by 1999 (Unni and Rani, 2000). A significant percentage of these informal sector workers are women involved in home-based piece-rate work.

Housing for the urban poor in Ahmedabad originated in the eastern half of the city where most textile mills were located (Field et al., 2008). These neighborhoods were usually segregated by caste (Gillion, 1968). The decline of textile mills, which began in the 1960s and accelerated in the 1980s, significantly increased informal sector employment among these workers (Breman, 2004). Today, their living arrangements largely consist of slums, which continue to remain organized along ethnic lines (Hall, 1980). While infrastructure in slums is poor, these neighborhoods remain close to the city's commercial center, where low-wage economic opportunities are most abundant (Bhatt, 2003).

\subsection{The Housing Lottery}

The housing scheme was organized by the Self Employed Women's Association (SEWA) Union, a collection of trade groups with a membership of over 500,000 women in Gujarat (SEWA, 2009). The SEWA beedi roller trade group was formed in $1978 .{ }^{10}$ Within the informal sector, the beedi industry is one of the few trades regulated by law — The Beedi and Cigar Workers Act. As the Act had a provision for government housing subsidies for beedi workers, the Union began to advocate for a subsidized group housing program. In interviews, Union officeholders described their key motivations as reducing housing costs and improving tenure security, both

$10 \quad$ Beedi rollers typically work at home on a piece-rate basis. An agent supplies raw materials and pays women for finished beedis that he then sells to beedi companies. The pay rate at the end of 2007 was about one dollar (INR 40-42 in 2007 USD) for 1,000 rolled beedis, which requires one day of work. 
of which were believed to contribute to school dropout among beedi workers' children.

In 1987, SEWA, in cooperation with multiple government agencies, launched a housing lottery for beedi workers. ${ }^{11}$ Union members with a monthly income of less than INR 700 (USD 11.28 currently) were eligible to participate, and all 497 eligible women entered the lottery. They came primarily from two caste groups, Koshti (35\%) and Padmasali (41\%), while Muslims (10\%) were the third largest group. SEWA leaders conducted the drawing of the 110 winners at a public gathering on International Housing Day in 1987.

After the lottery, the Union worked with the Ahmedabad Urban Development Authority (AUDA) to construct homes. The largest hurdle was finding suitable land. Six years later, AUDA built the houses on vacant government land situated 7.5 kilometers from the city center. The units were single-story row-houses of approximately 200 square feet situated back-to-back with a narrow alley running in between.

Units in Colony A were provided to winners at a substantial subsidy. The construction cost of the new homes was INR 45,000 (Dayal, 2001). Lottery winners paid a initial deposit of INR 900 and the paid INR 124 (about USD 2 currently) in monthly rent, a rate that was guaranteed for 20 years, and was less than half of the average rent these households reported they had been paying according to survey data. ${ }^{12} 13$

11 SEWA's website describes their contribution: “... the Housing and Urban Development Corporation (HUDCO) [provided] loans, Ahmedabad Urban Development Authority (AUDA) [identified] a piece of land under the scheme allocating land for the economically weaker sections and [built] the houses, the Beedi Workers Welfare Fund [provided] subsidies, ... the Gujarat Government's Ministry of Labour [sponsored] the scheme, SEWA [mobilized] the beedi workers, and SEWA Bank undertook the responsibility of collecting repayment of the loans."

12 Authors' calculations, available on request.

13 Winners were forbidden to sublease the property, although family members could occupy the residence. Failure to pay the monthly fee at any point resulted in the occupant losing the legal right to remain in the property. One unique feature of the program was that rent-to-own agreements with the government gave participants the opportunity to become homeowners after 20 years, but only under the unlikely scenario that all 110 winners remained in the colony and made regular monthly payments over the 20-year period. As expected, the colony failed to achieve zero delinquency/out-migration (a large fraction never even moved in), and so ultimately no one was given a title to the property, and today even tenants who made regular payments continue to be charged monthly rent to occupy the unit. Since this outcome was predictable, it arguably makes sense to treat the contract as a standard lease agreement. 


\subsection{Data Collection}

Conducting a follow-up survey involved the daunting task of tracking all lottery participants two decades after the lottery took place. Fortunately, the official list of lottery winners - which included participant name and address in Colony A - was available through SEWA Union. We obtained the names and addresses of lottery losers from multiple sources. First, the SEWA Union office maintained a list of 297 lottery losers (out of 387) that had indicated an interest in entering a future housing lottery. Second, a former SEWA employee provided a participant subset list that included names of an additional 26 lottery losers. ${ }^{14}$ In addition to names and addresses, this list of 109 participants also had a handful of baseline characteristics (1987 address, marital status, husband's occupation, and the incomes of the participant, husband and household) that we use in the proceeding section as part of a randomization check. Finally, we undertook tracking interviews with the listed lottery participants in an attempt to identify the remaining 64 (17\%) lottery losers. Ultimately, we obtained an additional 30 names (47\% of missing) as referrals from women who were in the lottery, and their participation was verified upon contact (from now on, "referrals list"). Hence, only 34 out of 387 lottery losers - or $9 \%$ of losers and $7 \%$ of all lottery participants - remained unidentified.

After constructing the participant list, we tracked and surveyed 443 participants (or a family member, in cases of death or mental illness), giving a response rate of $96 \%$ of the 463 participants who could be named ( $89 \%$ of the original 497 participants). No one refused the survey. Appendix Table 1 shows that attrition rates among the 463 listed participants were nearly identical across winners and non-winners (96\% for both groups), as were rates of mortality and proxy surveying. In subsection 2.4 we provide a randomization check for our tracked and surveyed sample to show that attrition from the set of named participants and inclusion on the participant list are uncorrelated with observable characteristics.

Our survey was conducted between May and October 2007, 20 years after the housing lottery and 14 years after lottery winners obtained possession of Colony A units. We asked respondents about household demographics, various socio-economic indicators, and the health, schooling,

14 In particular, two out of ten pages of the full list of all lottery participants were found by the employee. Those two pages contained 109 names, 26 of which were lottery losers not already found on the other list. 
marital status, and current occupation of their children. We also collected detailed data on their residential location and mobility over the last 20 years and obtained a full employment history for the participant and her husband. A neighborhood and networks module asked respondents about their social interactions with immediate neighbors and adult children, risk-sharing mechanisms (in terms of exposure to major city-level shocks in the last six years and the coping mechanisms they used to deal with them), and collective action undertaken over the last three years. We also collected GPS coordinates for participants' 1987 and 2007 residential locations.

Finally, in 2011 we hired a real estate agent to value a subset of current residences of lottery winners and losers (sampling and valuation procedure described in Section 3.1) and we conducted qualitative fieldwork with a random sample of 21 participants from four strata: five non-winners, four winners who never moved into Colony A, six winners who moved into Colony A but subsequently moved out, and six winners who still lived there. We used semistructured interviews to probe respondents on how their housing mobility opportunities affected their socioeconomic well-being and their networks.

\subsection{Descriptive Statistics and Empirical Strategy}

Our analysis sample encompasses the tracked and surveyed sample of 443 lottery participants. In Table 1 we use baseline (1987) data for this sample to provide descriptive statistics and a randomization balance check. Panel A considers participant demographics. At the time of lottery, average participant age was $28,88 \%$ were married and average number of children was 2.6. Beedi-rolling is a caste-based occupation, and the two main beedi-rolling castes, Padmasali and Koshti, make up over $75 \%$ of the sample. Participants typically rolled beedis at home and $12 \%$ of participants' husbands were tailors, a home-based occupation. However, close to half $(46 \%)$ of participants' husbands worked in a mill or factory located close to the city center. Participants were spread across 18 neighborhoods, with half of participants living in the innercity neighborhoods of Amraiwadi (11\%), Bapunagar (15\%), Dhudeshwar (12\%) and Rakhial $(13 \%)$. Seventy-six percent were located in the relatively dense East and Central administrative zones. 
Panel B presents characteristics of participants' residences at the time of the lottery. For ease of exposition and to reduce data-mining concerns, we group outcomes into three thematic indices: urbanicity, property rights, and amenities. To create each index, we take the simple average of $z$-scores for component outcomes. ${ }^{15}$ The urbanicity index includes distance (in miles) from home to city center, time to walk to nearest school and time to walk to nearest hospital. Appendix Table 2 shows that the average respondent lived 2.3 miles from the city center (measured as a straight line) and a 17-minute walk to the nearest school.

The property rights index includes participant home ownership in 1987, years of home ownership prior to 1987, whether possessed an official title, and whether title was in the participant's name. In this setting, interpretations of reported ownership are ambiguous because many of the residential structures in city slums are officially illegal, and occupants frequently claim ownership absent official documentation. Roughly $63 \%$ report that someone in their household owns the property (average length of ownership is just under seven years) and $50 \%$ claim to have some form of documentation. Just under $10 \%$ of participants say the documentation is in their name. We also calculate an amenities index that includes features of the residence, including whether the 1987 house had a separate kitchen, a private toilet, and a water connection, and a dummy indicator of whether it is safe for a woman to walk in the neighborhood after $10 \mathrm{pm}$.

We also asked respondents their reasons for choosing to live in each place. Over $30 \%$ report that they chose their 1987 location to be near family, and another $12 \%$ state that neighborhood resources drove their location choice. Only $3 \%$ named price as the main factor driving where they lived at the time of the lottery. ${ }^{16}$ For the arguably random subset list of 109 lottery applicants recovered from a former employee, we also have baseline income information, which we present in Panel C.

Comparing these baseline characteristics across winners and losers provides evidence that the lottery was indeed a random draw and that our survey attrition did not produce a biased set of comparison groups. In particular, winner and non-winner households looked very similar at the time of the lottery in virtually all observable dimensions. ${ }^{17}$ The only observed imbalance

$15 \quad$ Appendix Table 2 reports regressions for index components in their non-standardized form.

16 The remaining respondents listed either "other" or "for marriage" as the main factor.

17 Appendix Table 1, Panel B shows winners and non-winners among the subset of 109 also look identical to 
is that Muslims are over-represented in the non-winner category by 6.8 percentage points.

Given this imbalance, to further investigate whether Hindus were possibly favored in the housing draw, we regressed respondent perception of whether the lottery was conducted fairly on respondent religion and find no difference across Hindu and Muslim participants (though, unsurprisingly, winners are more likely to perceive the lottery as having been fair). ${ }^{18}$ Hence, we interpret the underrepresentation of Muslims among the winners as a random occurrence. That said, we present all experimental estimates with and without a dummy indicator of participant religion to absorb any variation in outcomes that might be driven by differences in treatment group composition.

Throughout the empirical analysis, we estimate

$$
Y_{i}=\alpha+\beta_{0} \cdot \text { winner }_{i}+X_{i} \cdot \gamma+\epsilon_{i}
$$

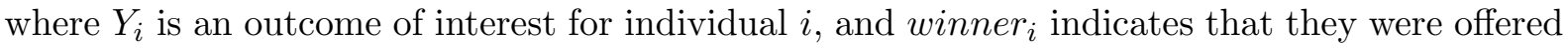
housing in Colony A. We report estimates with and without a set of controls $X_{i}$, which includes ethnic identity (indicators for whether the household is Muslim, Koshti caste, or Padmasali caste), a variable indicating whether the participant's name was referred by another member (rather than gathered from a Union list), and whether the participant's information was reported by proxy because she had died or was unable to answer due to mental illness. When the unit of observation is a child, we cluster standard errors at the participant level.

\section{Results}

We start by examining how winning the lottery in 1987 influenced a participant's residential mobility subsequent to the lottery including program take up (Table 2), and then investigate long-term economic outcomes (Tables 3-5). Each row reports the coefficient estimate of $\beta_{0}$ (from equation 1) from regressions of distinct outcome variables on the indicator of winning the lottery, without and with controls.

\footnotetext{
the full sample in terms of marital status, home distance to city center, and husbands' occupation. 18 Results available upon request.
} 


\subsection{Program Take-up}

The first row of Table 2 reveals that, although all winners signed the lease agreement, only $66 \%$ report moving into Colony A (60\% more than losers). In 2007, the average amount of time spent in Colony A was just over six years for winners (row 2). Fourteen years after program implementation, relative to losers, only $34 \%$ of winners still lived there (row 3 ).

Figure 1 plots the distribution of years spent in Colony A for the sample of winners. Approximately $60 \%$ of participants who moved in stayed on the property for at least 10 years, and $85 \%$ stayed at least five years. Hence, it is reasonable to anticipate significant relocation impacts on at least $85 \%$ of the movers, or over half of the winners. This also implies that the ITT estimates of program impact will be substantially diluted.

While low, take-up of Colony A housing is significantly higher than in comparable U.S. experiments, where observed lease rates among households offered location-restricted vouchers range between 19\% and 48\% (Rubinowitz and Rosenbaum, 2000; Kling et al., 2007; Ludwig et al., 2012; Jacob and Ludwig, 2012). However, unlike these experiments, the opportunity to lease a home in Colony A represented a significant financial opportunity. In particular, it entailed a substantially reduced rent and a large increase in tenure security for the average household in our sample (those moving from illegal to legal housing). ${ }^{19}$

The subsidy value could potentially be recovered through illegal sale or lease of the unit for those who did not take up the housing - and indeed the majority of winners who either did not move into Colony A or subsequently exited report selling or subletting their unit on the informal market. However, tenure security was not transferable and hence the value could not be fully recovered on the illegal market. Consistent with this, in section 3.2 we evaluate survey data on the magnitude of these (illegal) profits, and they are small and insignificant.

A major program objective was to reduce the frequency with which participants moved, which was believed to constrain children's schooling attainment. In qualitative interviews, winners consistently stated that Colony A provided tenure security and permanence that rental housing on the private market lacked and most winners recognized and appreciated the subsidized rent.

19 As described in Section 2.2, we estimate that SEWA offered units at a subsidy of at least 50\%. Anecdotally the change in tenure security was also high, although we cannot observe it precisely in our survey data. 
One winner who still lives in Colony A said: "[Tenure security] is very important. Otherwise, ... the landlord could say at any time leave the house. Every year we might have had to change houses." Said another, "I was [previously] paying 500 rupees as rent in Hatkeshwar but now I only pay 124 rupees as a monthly installment."

We collected detailed data on each residential location between 1987 (when they entered the lottery) and 2007 (when they answered the survey). In Table 2 we see that only $29 \%$ of participants resided in the same house at both points, and this number does not vary between lottery winners and losers. Because so many winners moved into and then out of Colony A, average residential mobility over the two decades is ultimately no lower among winners, with the average household reporting just over two relocations since 1987. Correspondingly, children of winners and non-winners report having to switch schools a comparable number of times (unreported).

We can thus infer from the take-up results that non-monetary costs - net of the rent received from illegal occupants - of moving from slum housing in the city center to Colony A were prohibitively large for the $66 \%$ of winners that sacrificed the stability, tenure security, and subsidized rent offered by the housing program. Given that these were all individuals who had chosen to participate in the lottery when the only unknown feature was the exact location of the housing development, we can presume that those who opted out did so because the difference between where they expected it to be and where it was actually built greatly changed its private value.

This interpretation is further supported by the fact that, in the open-ended survey question asked of winners who left Colony A, $76 \%$ of those that provided an answer named some aspect of geographic isolation as their primary reason for leaving Colony A. ${ }^{20}$ Furthermore, $31 \%$ of these individuals list "proximity to friends and family" as the major reason for choosing their current location, relative to only $3 \%$ of those who remained in Colony A. Below we evaluate the nature of these costs that ultimately led the housing program to fail by exploring a range of socio-economic outcomes correlated with lottery outcome.

20 The answer to this question was missing in 29 cases. 


\subsection{Urbanicity and Housing Quality}

Figures 2 and 3 show how lottery participants' residential patterns evolved over the 20-year period. Residences of lottery winners and losers were equally concentrated in central Ahmedabad in 1987, but over the next 20 years we observe increasing sprawl. Figure 3 shows that, by 2007, lottery participants are spread over a larger geographic area with a distinct cluster of winners located in Colony A.

We quantify this pattern by matching the administrative ward of participant's current residence with 2001 census data on population density. Table 3, rows (1) and (2) show that, while no less likely to have left the city, winners are significantly more likely to have left the city center for less dense suburban environs - they live in wards with roughly $30 \%$ lower population density. In row (3) we explore this further via the urbanicity index, which shows again that lottery winners report significantly lower urbanicity. Appendix Table 3 Panel A reports index components. Winners, on average, reside an additional mile away from the city center compared to non-winners, and there is a corresponding increase in the distance to health centers and schools.

The amenities index (row (4)) suggests that winners receive some degree of compensation via higher quality housing: regression estimates indicate a 0.2 standard deviation improvement in housing amenities among lottery winners, consistent with the goals of the program. ${ }^{21}$ Since winners and non-winners report similar value of housing improvements between 1987 and 2007 (row (5)), the difference presumably reflects higher quality housing provided by the program relative to the average slum residence.

Consistent with this pattern, rows (6)-(8) of Table 3 show that reported reasons for moving between 1987 and 2007 differed across lottery winners and losers. Non-winners more often report choosing current residence for proximity to family or friends (33\% versus $24 \%$ for winners) or local resources (29\% versus $17 \%$ ), while winners are more likely to choose residence for its price (34\% versus $9 \%$ for losers), which presumably reflects the low monthly cost at which Colony A

21 The component-wise analysis of the index (in Appendix Table 3 Panel B) shows that improvements in amenities reflect winner housing being more likely to have durable walls and roof, and have access to a private toilet. 
houses were offered to winners. Aggregation of participants' housing history data between 1987 and 2007 shows that, relative to losers, winners report living significantly fewer years in places chosen for proximity to family or amenities (rows 9 and 10).

Finally, to identify monetary implications of differences in neighborhood and housing quality across winners and losers, in 2011 we asked two real estate agents to value houses in neighborhoods where participants were concentrated in $2007 .{ }^{22}$ The two professional agents valued 109 houses in total, which cover $25 \%$ of non-winners and $22 \%$ of winners. ${ }^{23}$ We present the mid-point of the range of values agents' assigned to houses in the participants' neighborhoods (row 11) as a measure of neighborhood quality. Consistent with the previous evidence that the economic gains of higher value housing are offset by the geographic isolation of Colony A, housing prices in neighborhoods where winners reside are similar to those where non-winners reside 14 years after the lottery.

\subsection{Economic Well-being}

Table 4 examines traditional measures of economic well-being. Fourteen years after obtaining possession of Colony A housing, we observe strikingly few economic differences between lottery winners and non-winners, including key characteristics that have the potential to be influenced by residential location. Row 1 of Panel A shows that the adult labor supply index is unaffected by winning the lottery. Index components are reported in Appendix Table 3. The majority of participants and their husbands are currently employed and work roughly 40 hours per week. The only observable difference is that winners are less likely to hold a second job, though the propensity to have a second job is very low.

Next, we consider a labor supply cost index and again we do not observe significant differences. While the absence of employment effects on participants may reflect the home-based

22 We selected the five areas in the city that individually accounted for at least $5 \%$ of the surveyed participants. In each area we then selected neighborhoods that had at least three participants and sent the real estate agents to value the woman's home externally and houses in her immediate neighborhood. In Colony A, instead of valuing all nearly-identical homes and oversampling from one neighborhood, we valued $20 \%$ of the homes inhabited by lottery participants.

23 The slightly lower winner proportion reflects their high concentration in Colony A where we chose to value only $20 \%$ of participant homes to avoid oversampling from the largest neighborhood concentration of participants. 
nature of work, the absence of employment effects on husbands is more surprising given the documented change in distance from the city center. The latter is suggestive of those with job opportunities moving out of or failing to move into Colony A in response to potentially high labor supply costs. Reflecting the labor supply patterns, total and individual household members' labor incomes are virtually identical across groups (Panel A), with no visible difference in patterns of consumption, savings, or borrowing (Appendix Table 4).

These results are somewhat surprising given that, in qualitative interviews, many winners emphasized the relative isolation of Colony $\mathrm{A}$ in terms of employment opportunities. Women typically stated that, while fixed beedi rates meant that moving to Colony A left their own earnings unchanged, their husbands and children were affected by the lack of nearby low-skilled local jobs and the resulting increase in commuting costs. One resident who left Colony A after three years offered the following example:

"[My husband] was working at a public distribution system shop that was in Rakhial.

He continued working there, in the same shop, even after we moved to Colony A.

He used to ride his bicycle to work - it would take him one hour to get there. The commute was very difficult for him... Sometimes he would fall sick from exhaustion.

We also see no significant difference in housing income or expenses across winners and losers, despite the fact that rent in Colony A was highly subsidized and a non-trivial number of winners report leasing or selling their homes. In particular, we calculate housing costs between 1993 and 2007 as the sum of monthly rent paid over the period minus any income made from the lease or sale of property over this period. The point estimates indicate a small reduction in housing expenses from winning the lottery, which primarily comes from a non-trivial increase in income from the sale or lease of housing either inside or outside Colony A that is offset by a small increase in monthly rent over the 14 -year period (Table 4, Panel A).$^{24}$

24 Note that some of the increase in rental and sales income comes from lottery winners leasing or selling properties on which they resided prior to the lottery, and some of it comes from the illegal sale or lease of their apartment in Colony A. As of 2007, $15 \%$ of lottery winners report renting out the Colony A apartment and $45 \%$ had sold it (although they could not transfer a title since no winner obtained one). Although monthly rent was lower in Colony A than the average rental cost of units outside of Colony A, a significant number of those outside of Colony A report not paying rent at all over the period. 
Likewise, we observe no difference in wealth or well-being after 14 years across lottery winners and losers. The Asset Index values are virtually identical, as are demographics and investment in child and adult human capital. Panel B shows that winners and non-winners face similar post-lottery changes in fertility. A detailed family health index suggests similar health outcomes across the two groups. We also observe comparable levels of educational attainment for children in winner and non-winner households (completing 7.5 years of schooling on average), and these households face similar school transportation costs.

Nonetheless, the qualitative data indicate that some winners were adversely affected. One poignant example was offered by a winner who moved out after a few years" ${ }^{25}$ "My son got sick and had a very high fever which reached his brain. There were no medical facilities or proper doctors in Colony A who could help him. So, we decided to move to Bapunagar. Since then we have not been living in Colony A." Likewise, said the winner whose husband had to commute too far in Colony A: "The children were always getting sick. It was too tiring. ... In [our old neighborhood] Rakhial, schools and markets were all much closer. In Colony A everything was far away - taking the children to school took half an hour." The fact that we see no adverse human capital effects on average despite the fact that half of winners spent a significant amount of time in Colony A indicates that those who would have been negatively impacted by the move selected out of Colony A.

Tenure security was also unaffected by the program. In terms of home-ownership rates, ultimately none of the winners managed to purchase their home in Colony A by the end of the lease period (2013), so the program failed to increase rates of home ownership. ${ }^{26}$ Furthermore, while in theory public housing offers high tenure security through a standard lease arrangement, since two-thirds of the units were being occupied illegally at follow up, and the vast majority of winners still occupying their units were no longer making regular lease payments (both of which are grounds for losing occupancy rights in public housing), tenure security in Colony A was ultimately no stronger than that of illegal settlements in the slums. ${ }^{27}$

$25 \quad$ In the quantitative analysis, we saw that winners live farther from health facilities.

26 A significant fraction of both occupants and non-occupants stopped making monthly installments prior to completing the lease agreement, such that the opportunity for ownership was forfeited by all.

27 Administrative data from the bank indicate that ultimately only 11 winners occupied and made regular lease payments on their unit. 


\subsection{Social Capital}

Clearly the economic benefits offered by (though not realized by) the program were outweighed by certain costs that made it not worthwhile to take up housing in Colony A. Given the observed increase in geographic isolation, we next examine whether relocation also influenced the degree of social support households could rely on.

\subsubsection{Informal Insurance}

We first examine the degree to which respondents can borrow or lend through their social network, making use of four sets of questions in which the respondent was asked whom she borrows various items from or lends items to, and constructing a dummy indicator of whether they can borrow from or lend to anyone. ${ }^{28}$

On average, $93 \%$ of non-winners are members of at least one of the borrowing/lending networks. However, this number is nearly 10 percentage points lower for winners, and the difference is statistically significant. Winners also report knowing such a person for three fewer years, indicating that network ties have been severed in the act of relocating to Colony A. As detailed in Appendix Table 5 Panel A, in terms of who they rely upon, winners and non-winners are as likely to depend on (or support) someone from the same neighborhood (63\%). However, winners have known the people with whom they share risk for less time. Hence, it appears that winners are disproportionately losing network ties with those in their old neighborhood.

We also see direct evidence of changes in informal insurance by examining the occurrence of transfers in the event of shocks. The city of Ahmedabad experienced several city-wide shocks in the six years preceding our survey, including an earthquake in 2001, communal riots in 2002, and a viral epidemic (called Chikungunya) in 2006, such that almost all survey respondents (96\%) report experiencing personal damages (an average of roughly 30 days of work lost per event) from at least one of these specific events. Importantly, the likelihood, number, and severity in terms of work days lost of shocks reported is no different across winners and losers (Appendix

28 The four questions are: Who is the person you trust enough to lend INR 50 for 24 hours? Who is the person you would ask to borrow INR 50 from for 24 hours? Who is the person you would go to if you needed to borrow kerosene or rice for one day? In case of a health emergency, whom would you go to for borrowing INR 500? Appendix 2 presents regressions estimating these borrowing and lending outcomes individually. 
Table 5, Panel F). ${ }^{29}$

In general, risk-sharing in response to these shocks is very limited, and - consistent with the above evidence from hypothetical questions about availability of informal insurance - the incidence is significantly lower among lottery winners. Essentially, lottery losers report receiving an average of INR 71 (Table 5, Row (2)) in informal transfers in the event of a shock, and lottery winners report no informal help, and the difference is statistically significant. Thus, in both real and hypothetical scenarios, winners report less ability to rely on friends and family for help in the event of shocks.

One important limitation of informal insurance in this setting is that all three types of shocks - natural disasters, riots and disease epidemics - affect many people at the same time and are highly concentrated geographically, so are likely to hit a large fraction of network members simultaneously. This also may be the key reason that lottery winners - or those who are much more likely to have relocated to Colony A - have particularly weak informal insurance networks to cope with these shocks: if their networks are even more locally dense and geographically isolated, their ability to risk-share might be particularly compromised. ${ }^{30}$

\subsubsection{Social Interaction}

To understand the potential mechanisms through which informal insurance provision is lower in the suburbs, we next investigate respondents' social interactions, reported in Panel B of Table 5. We first look at family interaction. In row 1 we see that adult children on average live significantly farther away from lottery participants (non-resident children live an average of 1.3 miles away among lottery winners and 0.7 miles away among lottery non-winners). As seen in row 2 , distance between mothers and children results in less frequent social interaction. Winners are $5 \%$ less likely see an adult child at least monthly.

This pattern is consistent with the idea that greater average distances to employment op-

29 Conditional on experiencing at least one shock, the mean number of work days lost due to the shock was 28 , and the range was 0 to 142 days.

30 An alternative explanation is that winners have greater access to formal insurance, but this is not supported by survey data: $9 \%$ of non-winners received help from the government, an NGO or a religious organization following a shock, and among winners this fraction is lower by 6 percentage points without controls $(\mathrm{p}<.05)$ and by 4 percentage points $(\mathrm{p}<.1)$ with controls (Appendix Table 5, Panel F). 
portunities and neighborhood resources discourage adult children from staying in their parents' neighborhood. Indeed, the fact that adult sons' contribution to household income is comparable across winners and losers suggests that they are sacrificing geographic proximity to the family in order to maintain steady income and employment. This combination of findings indicates that the cost to participants of living in a remote area is primarily social isolation from immediate family members, rather than an economic disadvantage.

On the other hand, we do observe a compensating increase in social interaction with neighbors. Our survey asked respondents about each of the households that live in the four houses near them (across, behind, left and right) and how often they socialize through conversation, drinking tea together, or sharing a meal. The average respondent has 2.7 immediate neighbors, and this number is comparable across winners and losers (not shown). We use all responses to construct a pair-level dataset in which the unit of observation is at the respondent-neighbor level and cluster standard errors at the respondent level.

Overall, respondents' interaction with immediate neighbors is high, and significantly greater for those encouraged to relocate: $95 \%$ of pairs have ever socialized and this number is 3 percentage points higher for winners. This is particularly striking given that Colony A neighbors are $24 \%$ less likely to be from the same caste (Panel B, row (4)). The fact that they are more likely to be from the same occupation (row (7)) likely encourages interaction, as must the geographic isolation of Colony A.

These patterns provide an explanation for lower risk-sharing capacity among neighbors in Colony A. First of all, they are less connected in the sense that they are more likely to belong to a different caste and have known one another for less time, which could lower their ability to maintain otherwise optimal insurance agreements. Secondly, they are more likely to share the same occupation, so are more subject to correlated income shocks, which lowers the value of informal insurance agreements between neighbors.

In qualitative interviews, as well, a number of respondents described the social costs of geographic isolation. Many respondents who subsequently moved out reported feeling "scared" and "lonely" - especially since their husbands worked long hours in the city. The husband of 
one winner who left Colony A started his comments by saying, "The whole area was deserted and lonely - you could die there and no one would know it." The sense of loneliness was heightened by the fact that moving to Colony A increased distance from their relatives, and left many feeling socially disjunct from their community (caste) and family. He continued, "When we were living in Colony A we were very cut off from everyone. No one was inviting us to any functions." Poor transportation and the low prevalence of mobile phones in the 1990s increased the sense of isolation from the caste network.

In contrast, non-winners stated that their main network remains caste-based. One nonwinner who lives east of the old city explained, "There is a sense of community here - but it is along caste lines. People from our caste help us, but not others."

\subsubsection{Collective Action}

Another type of social interaction that is influenced by network composition is collective action, which we investigate in Panel C. Each respondent was asked about her participation in activities to benefit the community over the last three years. ${ }^{31}$ Roughly $19 \%$ of non-winners report contributing to community public goods over the last three years, and this percentage is almost twice as high among winners.

A potential explanation for greater engagement in cooperative behavior with neighbors is the flip side of the speculated reason for observing lower ability to risk-share associated with leaving the city center: denser local networks may facilitate cooperation around public goods that have highly localized benefits. That is, public goods that only benefit those within a certain geographic radius are likely to be easier to provide when neighborhood networks are less geographically disperse. ${ }^{32}$ In our survey data, the most common types of public goods provided informally by community members were precisely of this nature: gutters, road maintenance,

31 The specific question asked was, "What activities or problems have you worked on with your neighbors to benefit the community in the past three years?" The most common answers were: nothing, gutters, something for temple or mosque, wedding for a neighbor, funeral for a neighbor.

32 There are several potential mechanisms through which enforcement or incentives to contribute are likely to be greater when there is a higher degree of network density or closure. For example, individuals may value a given public good more if a higher fraction of her network members benefit from that good. Alternatively, it may be easier to enforce informal agreements to contribute if more beneficiaries of the public good can monitor and punish a potential beneficiary. 
temples, and local celebrations. The survey data also reveal that the vast majority of community public goods (91\%) involve contributions from all or most members of the community. If unanimity is required for public goods to be provided, this may be particularly difficult for members of diffuse networks to achieve. ${ }^{33}$

We also collected information on collective action outside of the neighborhood in the form of participation in the beedi worker union that all participants belonged to at the time of the lottery. Twenty years after the lottery, $87 \%$ of respondents still belong to the Union, and this number is almost identical across lottery winners and non-winners ( $86 \%$ and $88 \%$, respectively). However while roughly $47 \%$ of non-winners report having attended any Union meeting over the previous year, this number is 18 percentage points lower among winners.

This pattern provides further evidence that, due to geographic isolation, lottery winners invested less in collective action across neighborhoods and maintaining social ties with the broader community of beedi workers, and substituted toward more local ties that were less costly to maintain. Unfortunately, due to the high degree of spatial correlation in the major economic shocks such as floods, earthquakes, and riots, these more localized networks were not valuable in terms of providing informal insurance.

\subsection{Mobility versus Income Effects}

Thus far we have interpreted all of the ITT results as being driven by the compliers. That is, we have assumed that changes in social interactions, informal insurance and collective action are driven entirely by the two-thirds of lottery winners who moved to Colony A, and in some instances, by the one third of lottery winners who still live there. However, it is also possible that some of the patterns we observe reflect changes in long-run outcomes experienced by nonmovers, namely via a potential income effect of winning the lottery and renting out the unit. Distinguishing between these two stories is important for extrapolating our results to settings in which compliance rates are different, or enforcement of lease agreements is possible.

Since the set of movers are clearly a non-random sample of winners, it is difficult to rigorously

33 For example, the likelihood that one of the potential beneficiaries is unconnected to others in the network is greater if networks are less dense, so it will be harder to enforce that individual's contribution to the project. 
establish that program effects are disproportionately concentrated among them. However, there are three reasons to believe that this is the case. First, as shown in Table 6, in regressions run on winners only, in which outcomes are regressed on indicators of whether the respondent ever moved to Colony A and whether the respondent still lives in Colony A, all of the significant program effects found in the ITT results are found only among the subset of movers, and in many cases only among the subset that still live there now. In these regressions, the coefficient estimate on a dummy indicator of having moved to Colony A generates a point estimate that is significantly larger and more statistically significant than we observe in the ITT analysis, although it is impossible to rule out that movers look ex-ante different than non-movers in these dimensions.

Second, the estimated magnitudes of the program effects found in the ITT analysis are small enough that effect sizes up to three times as large (if concentrated only on those living in Colony A) are quite possible. For instance, it is entirely plausible that distance to non-co-resident children increases from 2 miles to 5.5 miles. In fact, if only one third of them live at home, and the rest return to the city center - which is 7.5 miles from Colony $\mathrm{A}$ - this is exactly the pattern we would expect to find in an ITT estimate.

Third, given that we in general find only negative effects of the program, there is not much room for income effects to be responsible for the patterns. For instance, there is no clear reason to believe that a modest income shock would lead to adult children living farther away from their parents, or lead to a lower ability to rely on network members for help.

\section{Conclusion}

Even among a group of slum dwellers who lobbied hard for the opportunity to move into public housing outside of the slums, ultimately very few found it optimal to leave the city center. Fourteen years after housing assignment, only $34 \%$ remained in public housing and the majority had returned to the slums. Evidence from other housing mobility programs suggests that the Colony A program was not an outlier. For instance, a survey conducted by us in 2007 of participants in another housing program in Ahmedabad (where beneficiaries were again chosen 
by lottery) showed that only $46 \%$ of winners or their relatives were living in the unit they won just two and a half years after winning it.

The main policy lesson is that it is very hard to make public housing relocation programs sufficiently attractive for the poor in developing countries to take them up, so this may rarely be the optimal policy response to housing concerns of slum populations. A major constraint appears to be the severance of social ties and the resulting loss of informal insurance that accompanies relocation, which was too costly to make even highly subsidized public housing in the suburbs worthwhile for most participants in our setting.

While policy-makers typically acknowledge costs of relocation programs such as increased commuting times or distance to health and education facilities, such costs can in theory be remedied with better public transportation or targeted suburban infrastructure. The destruction of social capital that comes from reshuffling slum communities is a welfare loss that cannot be so easily rebuilt. Although new ties may be formed eventually, slum relocation programs as they are normally envisioned destroy economically valuable social capital by severing links that may have evolved and strengthened in the neighborhood over decades and that likely result from the optimal sorting of individuals into enclaves.

Our findings suggest that alternative policies such as neighborhood-wide relocation programs may be more appropriate for slum-dwellers. Alternatively, slum upgrading programs that do not try to move people at all may be a less wasteful approach to public housing policy in developing countries.

\section{References}

Abu-Ghazzeh, T. M. (1999). Housing Layout, Social Interaction, and the Place of Contact in Abu-Nuseir, Jordan. Journal of Environmental Psychology XIX, 41-73.

Barnhardt, S. (2009). Near and Dear: Evaluating the Impact of Neighbor Diversity on InterReligious Attitudes. Ph. D. thesis, Harvard University. 
Bayer, P., S. L. Ross, and G. Topa (2008). Place of work and place of residence: Informal hiring networks and labor market outcomes. Journal of Political Economy 116(6), 1150-1196.

Bhatt, M. R. (2003). The Case of Ahmedabad, India. UNDERSTANDING SLUMS: Case Studies for the Global Report on Human Settlements.

Breman, J. (2004). The making and unmaking of an industrial working class: sliding down the labour hierarchy in Ahmedabad, India. Amsterdam: Amsterdam University Press.

Cities Alliance (2002). SEWA Bank's Housing Microfinance Program in India.

Coleman, J. (1990). Foundations of Social Theory. Cambridge, MA: Belknap.

Coleman, J. S. (1988). Social Capital in the Creation of Human Capital. American Journal of Sociology 94, S95-S120.

Dayal, M. (2001). Towards Securer Lives: SEWA's Social-security Programme. Orient Blackswan.

Festinger, L., S. Schachter, and K. Back (1963). Social Pressures in Informal Groups: A Study Of Human Factors in Housing. Stanford, CA: Stanford University Press.

Field, E. and M. Kremer (2006). Impact Evaluations for Slum Upgrading Interventions. Doing Impact Evaluation Series 3(3), 457-482.

Field, E., M. Levinson, R. Pande, and S. Visaria (2008). Segregation, Rent Control, and Riots: The Economics of Religious Conflict in an Indian City. American Economic Review 98, $505-510$.

Gillion, K. (1968). Ahmedabad; a Study in Indian Urban History. University of California Press.

Glaeser, E. (2011). Triumph of the City:How Our Greatest Invention Makes Us Richer, Smarter, Greener, Healthier, and Happier. Penguin Press.

Hall, D. (1980). A spatial analysis of urban community development policy in India, Volume 1. New York: Research Studies Press Ltd. 
Jacob, B. (2004). Public Housing Vouchers and Student Achievement: Evidence from Public Housing Demolitions in Chicago. American Economic Review 94, 233-258.

Jacob, B. and J. Ludwig (2012). The Effects of Housing Assistance on Labor Supply: Evidence from a Voucher Lottery. The American Economic Review 102.

Kapoor, M., S. Lall, M. Lundberg, and Z. Shalizi (2004). Location and Welfare in Cities: Impacts of Policy Interventions on the Urban Poor. World Bank Policy Research Working Paper No. 3318.

Kling, J., J. B. Liebman, and L. F.Katz (2007). Experimental Analysis of Neighborhood Effects. Econometrica 75, 83-119.

Lall, S. V., M. K. Lundberg, and Z. Shalizi (2008). Implications of alternate policies on welfare of slum dwellers: evidence from Pune, India. Journal of Urban Economics 63(1), 56-73.

Ludwig, J., G. J. Duncan, L. A. Gennetian, L. F. Katz, R. C. Kessler, J. R. Kling, and L. Sanbonmatsu (2012). Neighborhood effects on the long-term well-being of low-income adults. Science 337(6101), 1505-1510.

Ludwig, J., G. J. Duncan, L. A. Gennetian, L. F. Katz, R. C. Kessler, J. R. Kling, and L. Sanbonmatsu (2013a). Long-term neighborhood effects on low-income families: Evidence from moving to opportunity. The American Economic Review 103(3), 226-31.

Ludwig, J., G. J. Duncan, L. A. Gennetian, L. F. Katz, R. C. Kessler, J. R. Kling, and L. Sanbonmatsu (2013b). Online appendix to long-term neighborhood effects on low-income families: Evidence from moving to opportunity. The American Economic Review 103(3).

Marx, B., T. Stoker, and T. Suri (2013). The Economics of Slums in the Developing World. Journal of Economic Perspectives 27(4), 187-210.

Ministry of Housing and Urban Poverty Alleviation (2011). Toward more inclusive cities...

Ministry of Housing and Urban Poverty Alleviation (2013). Affordable Housing in Partnership: Scheme Guidelines. 
Montgomery, M. and P. Hewett (2005). Urban Poverty and Health in Developing Countries: Household and Neighborhood Effects. Demography 87(42), 397-425.

Office of the Registrar General, Census Commissioner (2001). Census of India.

Office of the Registrar General, Census Commissioner (2011). Ruralurban distribution. In Provisional Population Totals, Paper 2.

Oreopolous, P. (2003). The Long-Run Consequences of Living in a Poor Neighborhood. Quarterly Journal of Economics 118, 1533-1575.

Rubinowitz, L. S. and J. E. Rosenbaum (2000). Crossing the Class and Color Lines: From Public Housing to White Suburbia. Chicago: University of Chicago Press.

Sacerdote, B. and D. Marmaros (2006). How Do Friendships Form? Quarterly Journal of Economics 121(1), 79-119.

Sanbonmatsu, L., J. Ludwig, L. Katz, L. Gennetian, G. Duncan, R. Kessler, E. Adam, T. McDade, and S. T. Lindau (2011). Moving to Opportunity for Fair Housing Demonstration Program. Final Impacts Evaluation. U.S. Department of Housing and Urban Development, Office of Policy Development and Research.

SEWA (2009). SEWA's structure. http://www.sewa.org/About_Us_Structure.asp.

Takeuchi, A., M. Cropper, and A. Bento (2008). Measuring the welfare effects of slum improvement programs: The case of Mumbai. Journal of Urban Economics 64, 65-84.

U.N. Habitat (2003). The challenge of slums: global report on human settlements 2003. London: Earthscan.

UN High Commissioner for Refugees (2010). State of the World's Cities 2010/2011 - Cities for All: Bridging the Urban Divide. Nairobi: UNHCR (Habitat).

Unni, J. and U. Rani (2000). Urban informal sector: Size and income generation processes in Gujarat. National Council of Applied Economic Research Reports. (2). 
Viratkapan, V., R. Perera, and S. Watanabe (2004). Factors contributing to the development performance of slum relocation projects in Bangkok, Thailand. International Development Planning Review 26(3), 231-260.

Vithayathil, T. and G. Singh (2011). Spaces of Discrimination: Residential Segregation in Indian Cities. In Population Association of America Meeting, Washington, D.C.

Warah, R. (2004). Slums and Housing in Africa. UN Chronicle 40(4), 19, 28.

Ward, B. A. (2006). Essays on the Economics of Social Interaction. Ph. D. thesis, Harvard University. 
Table 1: Baseline (1987) Characteristics

\begin{tabular}{|c|c|c|c|}
\hline & Winner & Non-Winner Mean & $\mathrm{N}$ \\
\hline \multicolumn{4}{|l|}{ Panel A - Demographics } \\
\hline \multirow[t]{2}{*}{ Age } & 1.06 & 28.21 & 430 \\
\hline & $(1.14)$ & {$[9.95]$} & \\
\hline \multirow[t]{2}{*}{ Muslim } & $-0.07^{* *}$ & 0.12 & 443 \\
\hline & $(0.03)$ & {$[0.32]$} & \\
\hline \multirow[t]{2}{*}{ Padmasali Caste } & 0.07 & 0.39 & 443 \\
\hline & $(0.06)$ & {$[0.49]$} & \\
\hline \multirow[t]{2}{*}{ Koshti Caste } & -0.04 & 0.37 & 443 \\
\hline & $(0.05)$ & {$[0.48]$} & \\
\hline \multirow[t]{2}{*}{ Married } & -0.05 & 0.88 & 443 \\
\hline & $(0.04)$ & {$[0.33]$} & \\
\hline \multirow[t]{2}{*}{ Widowed, divorced, or separated } & 0.04 & 0.09 & 443 \\
\hline & $(0.04)$ & {$[0.28]$} & \\
\hline \multirow[t]{2}{*}{ Number children born } & -0.02 & 2.58 & 443 \\
\hline & $(0.25)$ & {$[2.17]$} & \\
\hline \multirow[t]{2}{*}{ Husband is employed } & -0.04 & 0.99 & 344 \\
\hline & $(0.03)$ & {$[0.11]$} & \\
\hline \multirow[t]{2}{*}{ Husband had a mill or factory job } & 0.09 & 0.49 & 344 \\
\hline & $(0.06)$ & {$[0.50]$} & \\
\hline \multirow[t]{2}{*}{ Husband had a tailoring job } & -0.05 & 0.13 & 344 \\
\hline & $(0.04)$ & {$[0.34]$} & \\
\hline \multicolumn{4}{|l|}{ Panel B - Residences } \\
\hline \multirow[t]{2}{*}{ Urbanicity Index } & 0.06 & -0.01 & 443 \\
\hline & $(0.07)$ & {$[0.65]$} & \\
\hline \multirow[t]{2}{*}{ Property Rights Index } & -0.01 & -0.01 & 443 \\
\hline & $(0.08)$ & {$[0.75]$} & \\
\hline \multirow[t]{2}{*}{ Amenities Index } & -0.05 & 0.00 & 427 \\
\hline & $(0.07)$ & {$[0.63]$} & \\
\hline \multirow[t]{2}{*}{ Chose location to be near family or friends } & 0.06 & 0.30 & 443 \\
\hline & $(0.05)$ & {$[0.46]$} & \\
\hline \multirow[t]{2}{*}{ Chose location for resources } & -0.01 & 0.12 & 443 \\
\hline & $(0.04)$ & {$[0.33]$} & \\
\hline \multirow[t]{2}{*}{ Chose location for price } & 0.01 & 0.03 & 443 \\
\hline & $(0.02)$ & {$[0.18]$} & \\
\hline \multicolumn{4}{|l|}{ Panel C - Income (subset) } \\
\hline \multirow[t]{2}{*}{ Participant's Income (INR per month) } & -15.65 & 268.15 & 109 \\
\hline & $(19.75)$ & [108.28] & \\
\hline \multirow[t]{2}{*}{ Husband's Income (INR per month) } & 43.65 & 334.31 & 109 \\
\hline & $(39.10)$ & {$[203.91]$} & \\
\hline
\end{tabular}

1. Each row reports OLS regression coefficient from a regression where the explanatory variable is whether the respondent won the lottery. Robust SE in ( ), standard deviations in [ ]. ${ }^{*} p<0.10,{ }^{* *} p<0.05,{ }^{* * *} p<0.01$ 2. Sample size less than 443 is due to missing observations except Panel A variables for husband since only 366 participants were married in 1987, and except Panel C, which is from the participant subset. 
3. The Urbanicity Index consists of miles from house to city center, minutes walk to nearest hospital and school. The Property Rights Index consists of whether they owned their home in 1987, how many years pre-1987 they owned their home, whether they owned the title and whether title was in the participant's name. A participant owns a house if someone in their household owns the house. The Amenities Index consists of whether the participant could walk outside at night up to 10 PM, whether they had a private toilet, a separate kitchen, and water tap in the house. 
Table 2: Program Take-up

\begin{tabular}{|c|c|c|c|c|}
\hline & \multicolumn{2}{|c|}{ Winner } & \multirow{2}{*}{$\begin{array}{c}\text { Non-winner } \\
\text { Mean }\end{array}$} & \multirow[t]{2}{*}{$\mathrm{N}$} \\
\hline & No Controls & With Controls & & \\
\hline Respondent's family ever lived in Colony $\mathrm{A}$ & $\begin{array}{c}0.60^{* * *} \\
(0.05)\end{array}$ & $\begin{array}{c}0.60^{* * *} \\
(0.05)\end{array}$ & $\begin{array}{c}0.06 \\
{[0.24]}\end{array}$ & 443 \\
\hline Years respondent lived in Colony A & $\begin{array}{l}6.08^{* * *} \\
(0.59)\end{array}$ & $\begin{array}{c}6.03^{* * *} \\
(0.60)\end{array}$ & $\begin{array}{c}0.39 \\
{[1.99]}\end{array}$ & 443 \\
\hline Respondent's Family Lives in Colony A & $\begin{array}{c}0.28^{* * *} \\
(0.05)\end{array}$ & $\begin{array}{c}0.28^{* * *} \\
(0.05)\end{array}$ & $\begin{array}{c}0.06 \\
{[0.24]}\end{array}$ & 443 \\
\hline Lives in same house as before lottery & $\begin{array}{l}-0.07 \\
(0.05)\end{array}$ & $\begin{array}{l}-0.05 \\
(0.05)\end{array}$ & $\begin{array}{c}0.29 \\
{[0.45]}\end{array}$ & 443 \\
\hline Number of houses lived in since 1987 & $\begin{array}{c}0.02 \\
(0.12)\end{array}$ & $\begin{array}{l}-0.00 \\
(0.12)\end{array}$ & $\begin{array}{c}2.16 \\
{[1.11]}\end{array}$ & 443 \\
\hline
\end{tabular}

1. We report OLS regression coefficients with robust SE in ( ), standard deviations in [ ].

${ }^{*} p<0.10,{ }^{* *} p<0.05,{ }^{* * *} p<0.01$

2. The set of controls is individual indicator variables for whether participant is Muslim, Koshti caste or

Padmasali castes (other castes omitted), whether participant was identified by referral, and whether a family member responded to the survey. 
Table 3: Current Housing and Neighborhood Quality

\begin{tabular}{lcccc}
\hline \hline & \multicolumn{2}{c}{ Winner } & Non-winner & N \\
& No Controls & With Controls & Mean & \\
\hline Lives in Ahmedabad in 2007 & -0.01 & 0.00 & 0.97 & 443 \\
& $(0.02)$ & $(0.02)$ & {$[0.18]$} & \\
Ward level population density & $-7375.10^{* * *}$ & $-7902.76^{* * *}$ & 29802.07 & 386 \\
Urbanicity Index & $(1432.47)$ & $(1412.91)$ & {$[10641.24]$} & \\
& $-0.34^{* * *}$ & $-0.36^{* * *}$ & -0.01 & 443 \\
Amenities Index & $(0.07)$ & $(0.07)$ & {$[0.61]$} & \\
& $0.20^{* * *}$ & $0.21^{* * *}$ & -0.00 & 443 \\
Total value of housing improvements & $(0.05)$ & $(0.05)$ & {$[0.46]$} & \\
made (INR 1000s) & -3.94 & -2.29 & 27.94 & 443 \\
Chose current location to be near & $(4.13)$ & $(4.00)$ & {$[58.51]$} & \\
family/friends & $-0.11^{* *}$ & $-0.09^{*}$ & 0.33 & 418 \\
Chose current location for & $(0.05)$ & $(0.05)$ & {$[0.47]$} & \\
resources & $-0.09^{*}$ & $-0.12^{* *}$ & 0.29 & 418 \\
Chose current location for price & $(0.05)$ & $(0.05)$ & {$[0.46]$} & \\
& $0.26^{* * *}$ & $0.25^{* * *}$ & 0.09 & 418 \\
Years lived in house to be close to & $(0.05)$ & $(0.05)$ & {$[0.28]$} & \\
family/friends & $-2.13^{* * *}$ & $-1.86^{* * *}$ & 6.30 & 442 \\
Years lived in house to be close to & $(0.70)$ & $(0.72)$ & {$[7.38]$} & \\
resources & $-1.69^{* * *}$ & $-2.21^{* * *}$ & 4.44 & 442 \\
Mid price of houses in area & $(0.63)$ & $(0.65)$ & {$[6.79]$} & \\
according to real estate agent (INR 1000s) & $(156.14)$ & $(154.10)$ & {$[633.21]$} & \\
\hline \hline
\end{tabular}

1. We report OLS regression coefficients with robust SE in ( ), standard deviations in [ ].

${ }^{*} p<0.10,{ }^{* *} p<0.05,{ }^{* * *} p<0.01$

2. The set of controls is individual indicator variables for whether participant is Muslim, Koshti caste or

Padmasali caste (other castes omitted), whether participant was identified by referral, and whether a family member responded to the survey.

3. Ward-level population density was obtained from Census data in 2001, and was only avaible for households still living in Ahmedabad in 2007.

4. The Urbanicity Index consists of miles from house to city center, number of houses in the neighborhood, and minutes walk to nearest hospital and school.

5. The Amenities Index consists of whether the participant could walk outside at night up to 10 PM, whether the house had a durable wall, roof, and floor; and whether they had a private toilet, a separate kitchen, and water tap in the house.

6. Choosing a house for its resources includes the following reasons: to be close to a school, work, for its location or for the area and neighbors. 
Table 4: Economic Well-Being

\begin{tabular}{|c|c|c|c|c|}
\hline 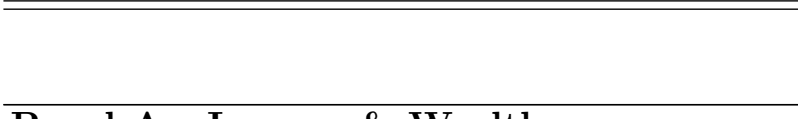 & \multicolumn{2}{|c|}{ Winner } & \multirow[t]{2}{*}{$\begin{array}{c}\text { Non-winner } \\
\text { Mean }\end{array}$} & \multirow[t]{2}{*}{$\mathrm{N}$} \\
\hline Panel A - Income \& Wealth & & & & \\
\hline Adult labor supply index & $\begin{array}{l}-0.04 \\
(0.08)\end{array}$ & $\begin{array}{l}-0.04 \\
(0.08)\end{array}$ & $\begin{array}{c}0.00 \\
{[0.71]}\end{array}$ & 414 \\
\hline Adult labor supply cost index & $\begin{array}{c}0.13 \\
(0.10)\end{array}$ & $\begin{array}{c}0.11 \\
(0.10)\end{array}$ & $\begin{array}{l}-0.01 \\
{[0.71]}\end{array}$ & 414 \\
\hline Participant currently rolls beedis & $\begin{array}{l}-0.03 \\
(0.05)\end{array}$ & $\begin{array}{l}-0.03 \\
(0.05)\end{array}$ & $\begin{array}{c}0.75 \\
{[0.43]}\end{array}$ & 414 \\
\hline Total household income (INR 100s per month) & $\begin{array}{l}-2.93 \\
(3.16)\end{array}$ & $\begin{array}{l}-3.22 \\
(3.18)\end{array}$ & $\begin{array}{c}42.05 \\
{[27.22]}\end{array}$ & 414 \\
\hline Participant income (INR 100s per month) & $\begin{array}{l}-0.52 \\
(0.56)\end{array}$ & $\begin{array}{l}-0.66 \\
(0.55)\end{array}$ & $\begin{array}{c}4.55 \\
{[4.03]}\end{array}$ & 414 \\
\hline Husband income (INR 100s per month) & $\begin{array}{c}-0.86 \\
(1.52)\end{array}$ & $\begin{array}{c}-0.73 \\
(1.55)\end{array}$ & $\begin{array}{c}10.83 \\
{[13.36]}\end{array}$ & 414 \\
\hline Income from sons (INR 100s per month) & $\begin{array}{l}-1.75 \\
(2.64)\end{array}$ & $\begin{array}{l}-2.13 \\
(2.67)\end{array}$ & $\begin{array}{l}22.95 \\
{[24.72]}\end{array}$ & 414 \\
\hline Income from daughters (INR 100s per month) & $\begin{array}{c}0.58 \\
(0.51)\end{array}$ & $\begin{array}{c}0.57 \\
(0.49)\end{array}$ & $\begin{array}{c}1.19 \\
{[3.83]}\end{array}$ & 414 \\
\hline Net housing revenue since 1993 (INR 1000s) & $\begin{array}{c}7.12 \\
(6.16)\end{array}$ & $\begin{array}{l}10.33 \\
(6.30)\end{array}$ & $\begin{array}{l}-13.14 \\
{[70.43]}\end{array}$ & 439 \\
\hline Asset Index & $\begin{array}{l}-0.00 \\
(0.04)\end{array}$ & $\begin{array}{c}0.01 \\
(0.04)\end{array}$ & $\begin{array}{l}-0.00 \\
{[0.41]}\end{array}$ & 443 \\
\hline Panel B - Human Capital & & & & \\
\hline Fertility since 1987 & $\begin{array}{l}-0.13 \\
(0.14)\end{array}$ & $\begin{array}{l}-0.08 \\
(0.14)\end{array}$ & $\begin{array}{c}1.08 \\
{[1.35]}\end{array}$ & 443 \\
\hline Health Index & $\begin{array}{l}-0.01 \\
(0.07)\end{array}$ & $\begin{array}{l}-0.03 \\
(0.07)\end{array}$ & $\begin{array}{l}-0.00 \\
{[0.56]}\end{array}$ & 443 \\
\hline Child's years schooling completed & $\begin{array}{l}-0.51 \\
(0.40)\end{array}$ & $\begin{array}{l}-0.17 \\
(0.35)\end{array}$ & $\begin{array}{c}7.54 \\
{[3.51]}\end{array}$ & 1491 \\
\hline $\begin{array}{l}\text { Child's mean home-school transport cost for } \\
\text { most recent school (INR per day) }\end{array}$ & $\begin{array}{l}-0.19 \\
(1.09)\end{array}$ & $\begin{array}{c}0.74 \\
(1.06)\end{array}$ & $\begin{array}{c}2.76 \\
{[10.34]}\end{array}$ & 1041 \\
\hline
\end{tabular}

1. We report OLS regression coefficients with robust SE in ( ), standard deviations in [ ].

${ }^{*} p<0.10,{ }^{* *} p<0.05,{ }^{* * *} p<0.01$

2. The set of controls is individual indicator variables for whether participant is Muslim, Koshti caste or Padmasali castes (other castes omitted), whether participant was identified by referral, and whether a family member responded to the survey. Regressions at the child level include child's gender as a control and participant-clustered SEs.

3. The Adult Labor Supply Index consists of whether the participant and husband work, number of hours worked, and whether the participant has a part-time job. The Adult Labor Supply Cost Index consists of whether participant has a job outside the home, and for the husband, whether his job required a commute, minutes taken to get to work, and money spent to go to work.

4. Income questions exclude deceased and incapacitated participants, whose families were not asked these questions. The sample for questions about husbands and children excludes 6 lottery participants who were never married. The sample for participant's work also excludes deceased and incapacitated participants. The sample for husband's work history excludes 63 participants whose husbands have not been in the household since before the 
lottery.

5. Net housing revenue was calculated from the amount reported made from selling or leasing houses minus the reported amount paid in mortgage and lease.

6. The Asset Index consists of whether the household owns each of the following: color television, motorcycle, rickshaw, bicycle, kerosene stove, ceiling fan, almirah, radio and mobile phone.

7. The Health Index consists of participant's current health status, months during which participant had health problems, participant has a persistent health problem, number of disease symptoms experienced by the participant in the last 30 days, and number of physical activities with which the respondent has health difficulties, as well as if anyone in the household required medical treatment in the past year, number of times someone was sick in the past year, if anyone had a health problem, number of breathing/coughing/backache problems participant has, if the husband has breathing/coughing/backache/alcoholism problems, and if any child has beedi-related health problem. 


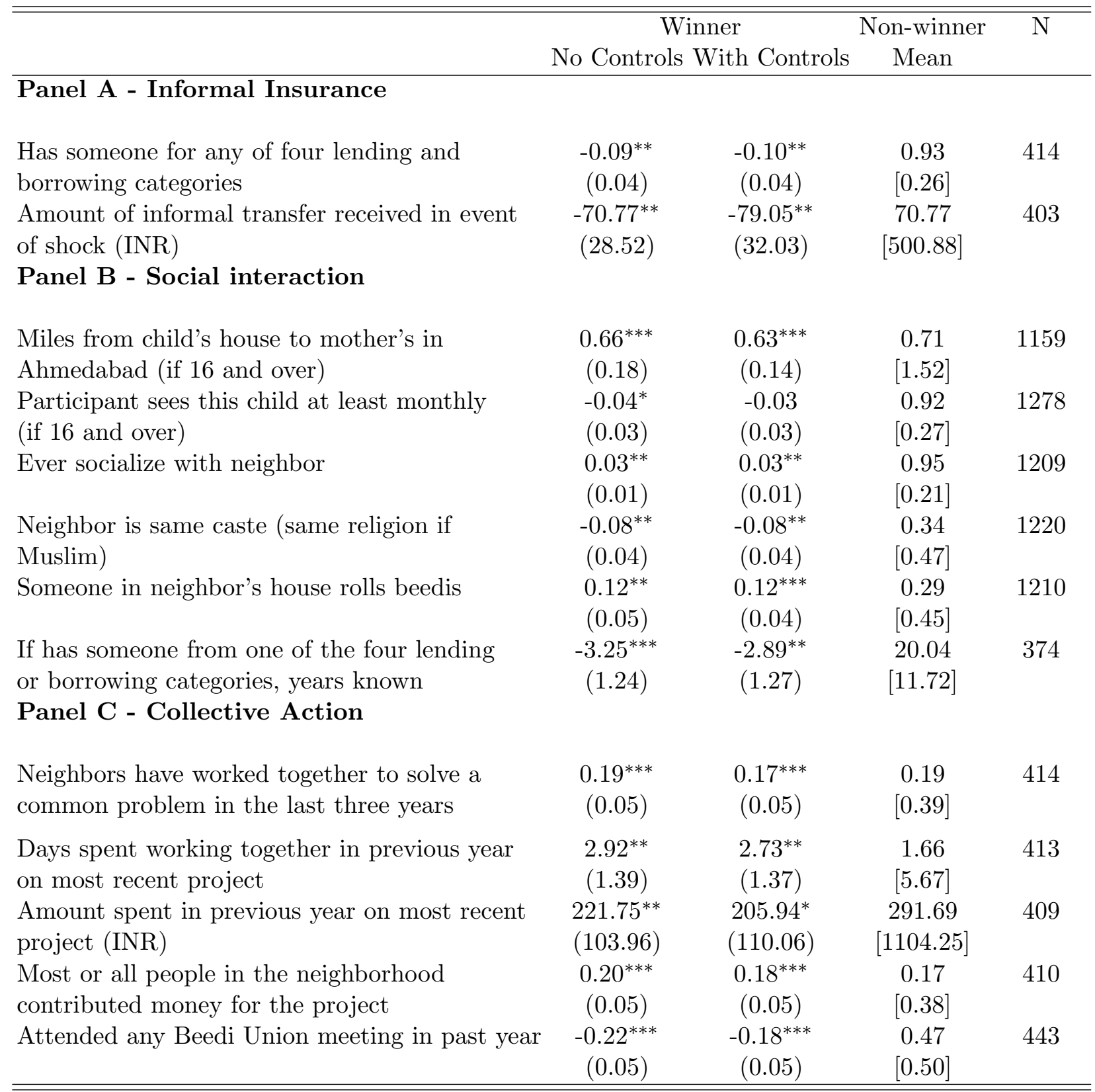

1. We report OLS regressions with robust SE in ( ), standard deviations in [ ]. ${ }^{*} p<0.10,{ }^{* *} p<0.05,{ }^{* * *} p<0.01$

2. The set of controls is individual indicator variables for whether participant is Muslim, Koshti caste or Padmasali castes, whether participant was identified by referral, and whether a family member responded to the survey. Regressions at the child level include the child's gender as a control and participant-clustered SEs. The immediate neighbor from same caste outcome exclude the caste and religion covariates.

3. Sample excludes participants who are dead or incapacitated. For immediate neighbors, sample consists of the four neighbors living left, right, front, and behind participants. 1220 neighbors reported. The number of neighbors was balanced across winners and non-winners. For these regressions, standard errors are clustered at the participant level.

4. "Has someone for lending or borrowing needs" combines whether they have (i) someone to borrow Rs. 50 from, (ii) someone you would lend Rs. 50 (iii) someone from whom you can borrow rice or cooking oil, and (iv) someone from whom you could borrow Rs. 500 for a health emergency.

5. Recent shocks asked about are communal riots, earthquake, and outbreak of the chikangunya virus. 
Table 6: Heterogeneity of Impact for Winners

\begin{tabular}{|c|c|c|c|c|}
\hline & $\begin{array}{c}\text { Lives in } \\
\text { Colony A }\end{array}$ & $\begin{array}{l}\text { Used to Live } \\
\text { in Colony A }\end{array}$ & $\begin{array}{c}\text { Mean if never } \\
\text { lived in Colony A }\end{array}$ & $\mathrm{N}$ \\
\hline \multicolumn{5}{|l|}{ Panel A - Housing and Income } \\
\hline Years lived in Colony A & $\begin{array}{c}12.08^{* * *} \\
(0.67)\end{array}$ & $\begin{array}{c}7.19^{* * *} \\
(0.70)\end{array}$ & $\begin{array}{c}0.00 \\
{[0.00]}\end{array}$ & 105 \\
\hline Chose current location for price & $\begin{array}{c}0.79^{* * *} \\
(0.08)\end{array}$ & $\begin{array}{l}-0.03 \\
(0.07)\end{array}$ & $\begin{array}{c}0.09 \\
{[0.29]}\end{array}$ & 98 \\
\hline Urbanicity Index & $\begin{array}{c}-0.75^{* * *} \\
(0.12)\end{array}$ & $\begin{array}{l}-0.29^{* *} \\
(0.14)\end{array}$ & $\begin{array}{c}0.01 \\
{[0.52]}\end{array}$ & 105 \\
\hline Amenities Index & $\begin{array}{c}0.09 \\
(0.09)\end{array}$ & $\begin{array}{l}-0.04 \\
(0.10)\end{array}$ & $\begin{array}{c}0.19 \\
{[0.42]}\end{array}$ & 105 \\
\hline $\begin{array}{l}\text { Total monthly household income (INR 100s per } \\
\text { month) } \\
\text { Panel B - Social Interactions }\end{array}$ & $\begin{array}{c}0.72 \\
(6.43)\end{array}$ & $\begin{array}{l}-3.02 \\
(7.20)\end{array}$ & $\begin{array}{c}39.84 \\
{[26.75]}\end{array}$ & 96 \\
\hline $\begin{array}{l}\text { Neighbors have worked together to solve a } \\
\text { common problem in the last three years }\end{array}$ & $\begin{array}{c}0.57^{* * *} \\
(0.10)\end{array}$ & $\begin{array}{c}0.07 \\
(0.10)\end{array}$ & $\begin{array}{c}0.16 \\
{[0.37]}\end{array}$ & 96 \\
\hline $\begin{array}{l}\text { Has someone for any of four lending and } \\
\text { borrowing categories }\end{array}$ & $\begin{array}{l}0.22^{* *} \\
(0.09)\end{array}$ & $\begin{array}{c}0.12 \\
(0.11)\end{array}$ & $\begin{array}{c}0.72 \\
{[0.46]}\end{array}$ & 96 \\
\hline Attended beedi union meeting in past year & $\begin{array}{l}-0.15 \\
(0.10)\end{array}$ & $\begin{array}{l}-0.05 \\
(0.11)\end{array}$ & $\begin{array}{c}0.31 \\
{[0.47]}\end{array}$ & 105 \\
\hline Someone in neighbor's house rolls beedis & $\begin{array}{c}0.45^{* * *} \\
(0.08)\end{array}$ & $\begin{array}{l}-0.08 \\
(0.08)\end{array}$ & $\begin{array}{c}0.25 \\
{[0.43]}\end{array}$ & 291 \\
\hline $\begin{array}{l}\text { Winner and neighbor are same caste (same } \\
\text { religion if Muslim) }\end{array}$ & $\begin{array}{c}0.02 \\
(0.08)\end{array}$ & $\begin{array}{l}-0.03 \\
(0.08)\end{array}$ & $\begin{array}{l}0.25 \\
{[0.44]}\end{array}$ & 296 \\
\hline $\begin{array}{l}\text { Participant sees this child at least monthly } \\
\text { (if } 16 \text { and over) }\end{array}$ & $\begin{array}{l}-0.09^{*} \\
(0.05)\end{array}$ & $\begin{array}{l}-0.04 \\
(0.05)\end{array}$ & $\begin{array}{c}0.93 \\
{[0.26]}\end{array}$ & 290 \\
\hline $\begin{array}{l}\text { Miles from child's house to mother's in } \\
\text { Ahmedabad (if } 16 \text { and over) }\end{array}$ & $\begin{array}{l}0.71^{*} \\
(0.43)\end{array}$ & $\begin{array}{l}-0.23 \\
(0.42)\end{array}$ & $\begin{array}{l}1.15 \\
{[1.79]}\end{array}$ & 254 \\
\hline
\end{tabular}

1. We report OLS regressions with robust SE in ( ), standard deviations in [ ]. ${ }^{*} p<0.10,{ }^{* *} p<0.05,{ }^{* * *} p<0.01$

2. For regressions at the child level and the neighbor level standard errors are clustered at the participant level. 


\section{Figures}

Figure 1: Years Lived in Colony A (only Winners)

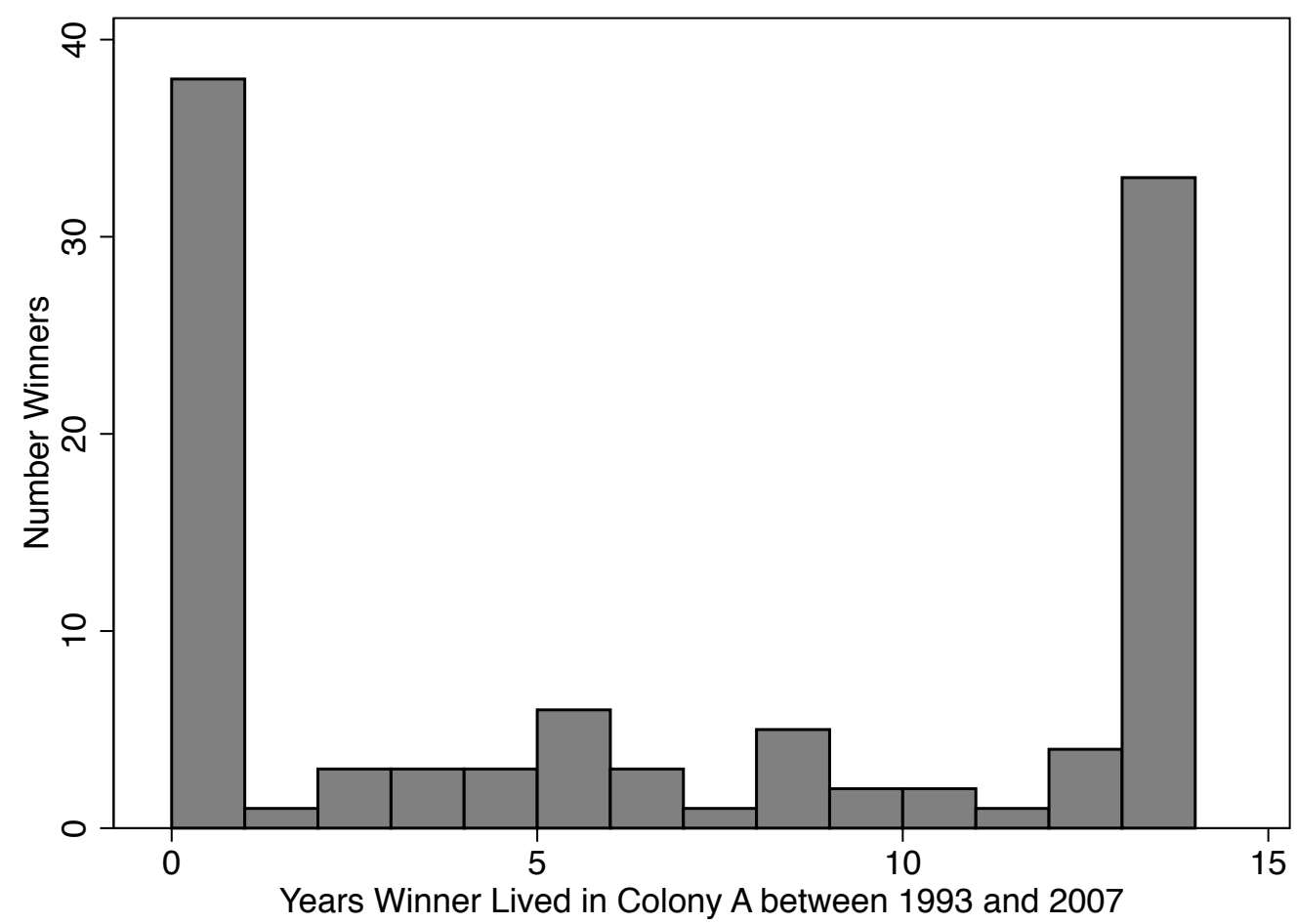


Figure 2: Housing Locations 1987

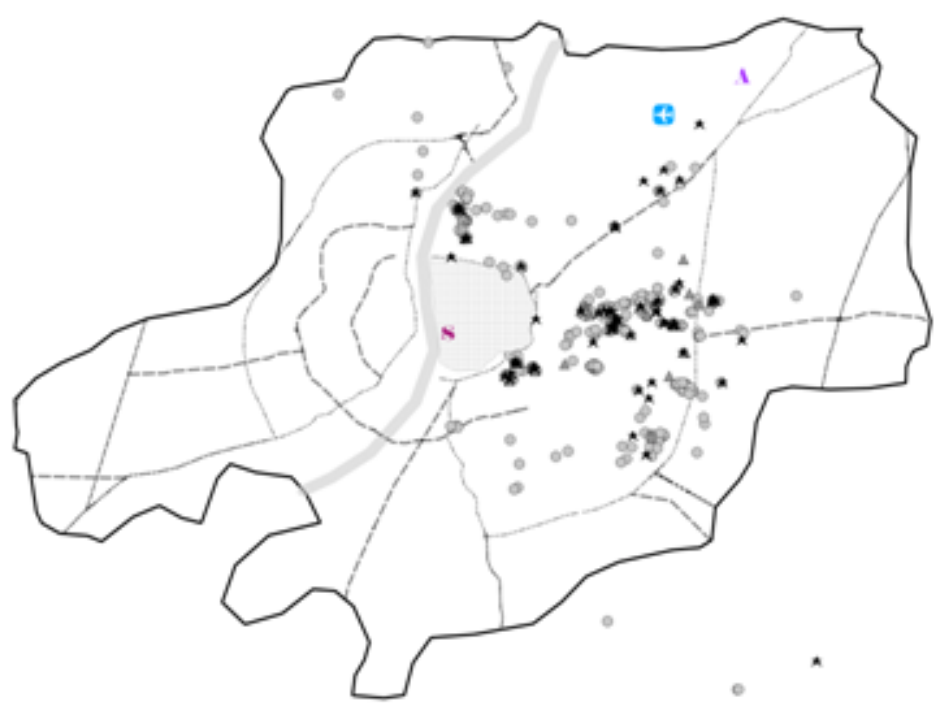

Figure 3: Housing Locations 2007

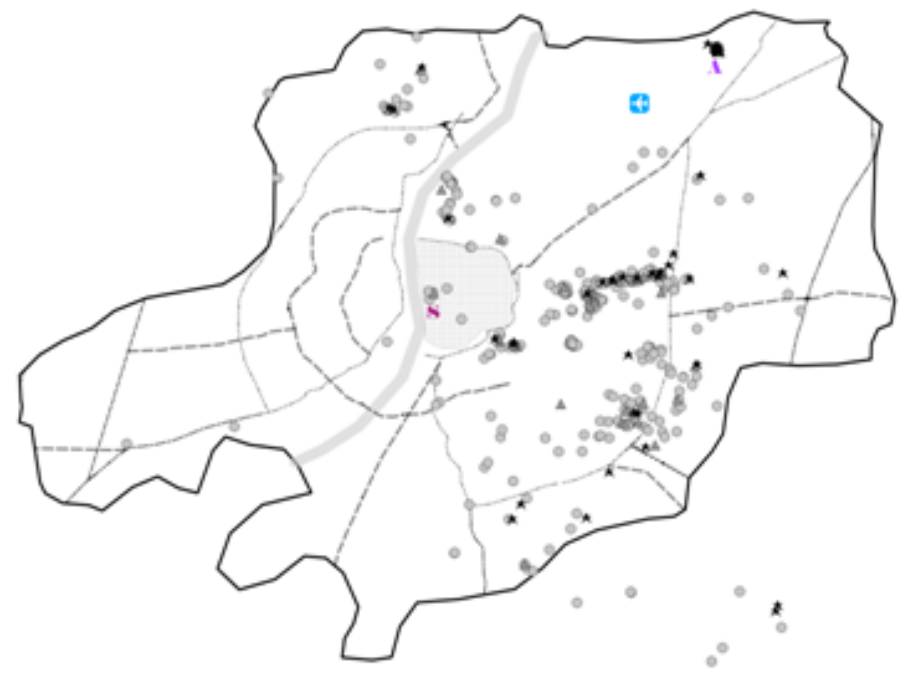

\section{Legend}

$\star$ Winner - family moved to Colony A

A. Winner - never moved to Colony A

- Non-winner

Landmarks

(4) Airport

A Colony A

s SEWA Union Headquarters Old City

Ahmedabad Highways (OpenStreetMap map data -Last maps update: 13 December 2011)

-..-.- motorway

--- primary

-... trunk

Sabarmati River

Ahmedabad City 


\section{Appendix}

\section{A. Tracking Protocol}

If a participant no longer lived at the address on one of the lists (winners, second lottery or participant subset) then we asked neighbors where to find her. In addition, we searched for participants' names on recent SEWA Union membership rolls and in SEWA Bank client records. Several women who work for different branches of SEWA - the Union, the Bank, and the Insurance group - also helped us identify participants. The main organizers of the 1987 lottery scrutinized the lists for names they recognized. We also read out a list of unfound participants at a Union meeting in April 2007. In addition to SEWA, we used other beedi networks to locate participants and talked to important beedi agents in areas where many beedi workers lived in 1987. Finally, we looked for names of the unfound women on the 2004 Ahmedabad electoral rolls.

Of the 463 named participants, 23 women had left Ahmedabad. We tracked 17 of them as far as Mumbai, Hyderabad, and Chennai. Another 29 women had died, and we were able to locate the children or husband of 25 of them. An additional four women were located, but were incapacitated and unable to answer the survey; their families were surveyed in their place. We were unable to track a final address for 10 women. 


\section{B. Appendix Tables}

Appendix Table 1: Tracking and Baseline Characteristics

\begin{tabular}{|c|c|c|c|}
\hline & Winner & Non-Winner Mean & $\mathrm{N}$ \\
\hline \multicolumn{4}{|l|}{ Panel A - Tracking and Surveying } \\
\hline \multirow[t]{2}{*}{ Participant or family was found } & -0.00 & 0.96 & 463 \\
\hline & $(0.02)$ & {$[0.20]$} & \\
\hline \multirow[t]{2}{*}{ Participant has died } & 0.01 & 0.05 & 443 \\
\hline & $(0.03)$ & {$[0.22]$} & \\
\hline \multirow[t]{2}{*}{ Referred participant was found for survey } & 0.02 & 0.98 & 85 \\
\hline & $(0.02)$ & {$[0.16]$} & \\
\hline \multirow[t]{2}{*}{ Family surveyed due to participant death/ incapacity } & 0.03 & 0.06 & 443 \\
\hline & $(0.03)$ & {$[0.24]$} & \\
\hline \multicolumn{4}{|l|}{ Panel B - Baseline Characteristics } \\
\hline \multirow[t]{2}{*}{ Widowed } & -0.04 & 0.11 & 109 \\
\hline & $(0.05)$ & {$[0.31]$} & \\
\hline \multirow[t]{2}{*}{ Married } & 0.06 & 0.80 & 109 \\
\hline & $(0.07)$ & {$[0.40]$} & \\
\hline \multirow[t]{2}{*}{ Miles to city center from house } & 0.09 & 2.49 & 108 \\
\hline & $(0.15)$ & {$[0.75]$} & \\
\hline \multirow[t]{2}{*}{ Husband had a mill or factory job } & 0.11 & 0.43 & 99 \\
\hline & $(0.10)$ & {$[0.50]$} & \\
\hline \multirow[t]{2}{*}{ Husband had a tailoring job } & -0.10 & 0.22 & 99 \\
\hline & $(0.08)$ & {$[0.42]$} & \\
\hline
\end{tabular}

Each row reports results from a separate OLS regression. The outcome variable is reported in column 1.

The winner column reports the coefficient on the winner dummy. Robust SE in ( ), standard deviations in [].

${ }^{*} p<0.10,{ }^{* *} p<0.05,{ }^{* * *} p<0.01$ 
Appendix Table 2: Breakdown of Baseline Indices

\begin{tabular}{|c|c|c|c|}
\hline & Winner & Non-Winner Mean & $\mathrm{N}$ \\
\hline \multicolumn{4}{|l|}{ Panel A - Urbanicity Index } \\
\hline \multirow[t]{2}{*}{ Miles from city center to house } & 0.05 & 2.28 & 442 \\
\hline & $(0.12)$ & {$[0.94]$} & \\
\hline \multirow[t]{2}{*}{ Minutes walk to nearest government school } & -1.98 & 16.99 & 427 \\
\hline & $(1.24)$ & {$[13.92]$} & \\
\hline \multirow[t]{2}{*}{ Minutes walk to nearest government hospital } & -2.24 & 32.17 & 427 \\
\hline & $(2.28)$ & {$[21.19]$} & \\
\hline \multicolumn{4}{|l|}{ Panel B - Property Rights } \\
\hline \multirow[t]{2}{*}{ Owned home } & -0.01 & 0.63 & 427 \\
\hline & $(0.06)$ & {$[0.48]$} & \\
\hline \multirow[t]{2}{*}{ Number of years owned home pre- 1987} & -0.49 & 6.41 & 443 \\
\hline & $(0.98)$ & {$[8.91]$} & \\
\hline \multirow[t]{2}{*}{ Had the title } & 0.02 & 0.50 & 443 \\
\hline & $(0.06)$ & {$[0.50]$} & \\
\hline \multirow[t]{2}{*}{ Had the title in participant's name } & 0.00 & 0.09 & 443 \\
\hline & $(0.03)$ & {$[0.29]$} & \\
\hline \multicolumn{4}{|l|}{ Panel C - Amenities Index } \\
\hline \multirow[t]{2}{*}{ Woman safe walking alone after 10 PM in 1987} & 0.02 & 0.86 & 407 \\
\hline & $(0.04)$ & {$[0.34]$} & \\
\hline \multirow[t]{2}{*}{ Had private toilet } & -0.05 & 0.55 & 425 \\
\hline & $(0.06)$ & {$[0.50]$} & \\
\hline \multirow[t]{2}{*}{ Had separate kitchen } & -0.00 & 0.45 & 420 \\
\hline & $(0.06)$ & {$[0.50]$} & \\
\hline \multirow[t]{2}{*}{ Has water in home } & -0.05 & 0.87 & 426 \\
\hline & $(0.04)$ & {$[0.34]$} & \\
\hline
\end{tabular}

1. We report OLS regression coefficients with robust SE in ( ), standard deviations in [ ].

${ }^{*} p<0.10,{ }^{* *} p<0.05,{ }^{* * *} p<0.01$

2. Minutes spent going to work is for a single one-way trip.

3. As opposed to the Amenities Index in 2007, the Amenities Index at baseline does not include Durable wall, Durable roof and Durable floor. These variables were indeed not available for housing in 1987. Similarly, the Urbanicity Index at baseline does not include Number of Houses within a 5 minute walk since this information was not available for housing in 1987. 
Appendix Table 3: Breakdown of Outcome Indices

\begin{tabular}{|c|c|c|c|c|}
\hline & \multicolumn{2}{|c|}{ Winner } & \multirow{2}{*}{$\begin{array}{c}\text { Non-winner } \\
\text { Mean }\end{array}$} & \multirow[t]{2}{*}{$\mathrm{N}$} \\
\hline & No Controls & With Controls & & \\
\hline \multicolumn{5}{|l|}{ Panel A - Urbanicity } \\
\hline \multirow[t]{2}{*}{ Miles from city center to house } & $1.09^{* * *}$ & $1.08^{* * *}$ & 2.88 & 423 \\
\hline & $(0.19)$ & $(0.19)$ & {$[1.31]$} & \\
\hline \multirow[t]{2}{*}{ Number of houses within a 5 minute walk } & -24.84 & -25.96 & 114.98 & 406 \\
\hline & $(15.31)$ & $(15.94)$ & {$[170.55]$} & \\
\hline \multirow[t]{2}{*}{ Minutes walk to nearest government school } & 1.74 & $2.43^{*}$ & 15.12 & 443 \\
\hline & $(1.33)$ & $(1.38)$ & {$[12.30]$} & \\
\hline \multirow[t]{2}{*}{ Minutes walk to nearest government hospital } & $7.80^{* * *}$ & $9.22^{* * *}$ & 33.44 & 443 \\
\hline & $(2.61)$ & $(2.70)$ & {$[24.16]$} & \\
\hline \multicolumn{5}{|l|}{ Panel B - Amenities } \\
\hline \multirow[t]{2}{*}{ Woman safe walking alone after $10 \mathrm{PM}$} & -0.06 & -0.06 & 0.84 & 438 \\
\hline & $(0.05)$ & $(0.05)$ & {$[0.37]$} & \\
\hline \multirow[t]{2}{*}{ Durable wall } & $0.15^{* * *}$ & $0.15^{* * *}$ & 0.08 & 442 \\
\hline & $(0.04)$ & $(0.04)$ & {$[0.28]$} & \\
\hline \multirow[t]{2}{*}{ Durable roof } & $0.20^{* * *}$ & $0.18^{* * *}$ & 0.61 & 435 \\
\hline & $(0.05)$ & $(0.05)$ & {$[0.49]$} & \\
\hline \multirow[t]{2}{*}{ Durable floor } & 0.01 & 0.01 & 0.99 & 435 \\
\hline & $(0.00)$ & $(0.01)$ & {$[0.08]$} & \\
\hline \multirow[t]{2}{*}{ Has private toilet } & $0.12^{* * *}$ & $0.11^{* * *}$ & 0.80 & 442 \\
\hline & $(0.03)$ & $(0.04)$ & {$[0.40]$} & \\
\hline \multirow[t]{2}{*}{ Has separate kitchen } & $0.09^{*}$ & $0.09^{*}$ & 0.64 & 441 \\
\hline & $(0.05)$ & $(0.05)$ & {$[0.48]$} & \\
\hline \multirow[t]{2}{*}{ Has water in home } & 0.03 & 0.04 & 0.88 & 442 \\
\hline & $(0.03)$ & $(0.04)$ & {$[0.33]$} & \\
\hline \multicolumn{5}{|l|}{ Panel C - Asset Index } \\
\hline \multirow[t]{2}{*}{ Amount saved (INR 1000s) } & -1.14 & -1.01 & 4.15 & 409 \\
\hline & $(1.63)$ & $(1.61)$ & {$[25.48]$} & \\
\hline \multirow[t]{2}{*}{ Quality television in the house? } & -0.03 & -0.02 & 0.72 & 442 \\
\hline & $(0.04)$ & $(0.04)$ & {$[0.38]$} & \\
\hline \multirow[t]{2}{*}{ Household owns a motorcycle? } & -0.02 & -0.01 & 0.23 & 442 \\
\hline & $(0.05)$ & $(0.04)$ & {$[0.42]$} & \\
\hline \multirow[t]{2}{*}{ Household owns a rickshaw? } & 0.00 & 0.01 & 0.06 & 443 \\
\hline & $(0.03)$ & $(0.03)$ & {$[0.23]$} & \\
\hline \multirow[t]{2}{*}{ Household owns a bicycle? } & -0.01 & -0.01 & 0.76 & 443 \\
\hline & $(0.05)$ & $(0.05)$ & {$[0.43]$} & \\
\hline \multirow[t]{2}{*}{ Household owns a kerosene stove? } & 0.04 & 0.02 & 0.41 & 442 \\
\hline & $(0.06)$ & $(0.05)$ & {$[0.49]$} & \\
\hline \multirow[t]{2}{*}{ Household owns a ceiling fan? } & $0.05^{*}$ & $0.06^{* *}$ & 0.93 & 443 \\
\hline & $(0.02)$ & $(0.02)$ & {$[0.25]$} & \\
\hline Household owns a almirah? & 0.02 & 0.04 & 0.51 & 443 \\
\hline & $(0.06)$ & $(0.06)$ & {$[0.50]$} & \\
\hline Household owns a radio? & -0.06 & -0.08 & 0.35 & 443 \\
\hline
\end{tabular}


Household owns a mobile phone?

\section{Panel D - Adult Labor Supply Index}

Fraction of participant and husband currently working

Participant and husband mean weekly hours currently working

Participant has another part-time job

\section{Panel E - Adult Labor Supply Cost Index}

Participant's current work is outside the

home

Husband's job requires commute

Amount husband spent going to work (INR)

Minutes husband spent going to work

\section{Panel F - Health Index}

Participant current health status $(1=$ Worst than ave, $5=$ Better than ave)

Months during which participant had health problems

Participant has current persistent health problem

Number of disease symptoms experienced in last 30 days

Number of physical activities with which respondent has health difficulties

Any member of household required medical treatment in past year

Number of times member of household was sick in past year

At least 1 person in the household has a serious health issue

Participant's number of breathing, cough or backache problems

Husband's number of breathing, cough, backache or alcoholism problems Child currently has beedi-related health problem
$-0.01$

$(0.06)$

$(0.05)$

[0.48]

0.47

[0.50]

(0.06)

$-0.01$

(0.04)

1.62

(2.28)

$-0.03^{* *}$

(0.02)

$-0.02$

(0.04)

1.57

(2.30)

$-0.03^{*}$

(0.02)

0.84

[0.30]

40.06

[18.58]

0.04

$[0.20]$

0.02

(0.03)

0.06

(0.06)

0.88

(1.21)

0.84

(2.04)

0.01

(0.03)

0.07

(0.06)

0.73

(1.22)

0.80

(2.16)

0.07

[0.25]

0.68

[0.47]

2.88

[8.27]

10.31

[14.21]

0.08

(0.10)

2.24

(3.36)

$-0.02$

(0.03)

$-0.01$

(0.18)

$-0.01$

(0.08)

$-0.02$

(0.05)

0.16

(0.13)

0.04

$(0.05)$

0.00

(0.07)

0.05

(0.06)

0.07

(0.04)
0.04

(0.10)

3.14

(3.30)

$-0.01$

(0.03)

0.02

(0.18)

0.01

(0.08)

$-0.01$

(0.05)

0.21

(0.13)

0.05

(0.06)

$-0.01$

(0.07)

0.01

(0.06)

0.06

(0.05)
3.35

[0.88]

6.16

$[21.78]$

0.09

[0.29]

1.21

[1.50]

0.28

[0.72]

0.80

$[0.40]$

1.21

[0.97]

0.36

[0.48]

0.31

$[0.59]$

0.13

[0.39]

0.11

$[0.31]$
287

414

414

414

414

291

287

413

411

413

413

414

442

435

443

407

291

399

1. We report OLS regressions with robust SE in ( ), standard deviations in [ ]. ${ }^{*} p<0.10,{ }^{* *} p<0.05,{ }^{* * *} p<0.01$ 
Appendix Table 4: Expenditures and Financial

\begin{tabular}{|c|c|c|c|c|}
\hline & \multicolumn{2}{|c|}{ Winner } & \multirow{2}{*}{$\begin{array}{c}\text { Non-winner } \\
\text { Mean }\end{array}$} & \multirow[t]{2}{*}{$\mathrm{N}$} \\
\hline & No Controls & With Controls & & \\
\hline \multicolumn{5}{|l|}{ Panel A - Monthly Expend } \\
\hline Vegetables and fruit & $\begin{array}{l}-65.02^{*} \\
(33.93)\end{array}$ & $\begin{array}{l}-38.54 \\
(34.31)\end{array}$ & $\begin{array}{c}677.11 \\
{[379.67]}\end{array}$ & 414 \\
\hline Travel and transport (excluding commute) & $\begin{array}{c}5.27 \\
(24.19)\end{array}$ & $\begin{array}{c}0.86 \\
(24.39)\end{array}$ & $\begin{array}{c}83.90 \\
{[201.71]}\end{array}$ & 414 \\
\hline Medicine, clothing and school fees & $\begin{array}{c}2.19 \\
(118.80)\end{array}$ & $\begin{array}{c}35.13 \\
(118.01)\end{array}$ & $\begin{array}{c}681.28 \\
{[1106.19]}\end{array}$ & 414 \\
\hline Temptation goods & $\begin{array}{c}85.62 \\
(65.37)\end{array}$ & $\begin{array}{c}74.97 \\
(66.14)\end{array}$ & $\begin{array}{c}303.24 \\
{[405.72]}\end{array}$ & 414 \\
\hline Home and durable goods repairs & $\begin{array}{c}28.65 \\
(19.24)\end{array}$ & $\begin{array}{c}32.10 \\
(19.53)\end{array}$ & $\begin{array}{c}73.00 \\
{[130.59]}\end{array}$ & 414 \\
\hline Telephone & $\begin{array}{c}8.93 \\
(21.70)\end{array}$ & $\begin{array}{c}0.94 \\
(24.59)\end{array}$ & $\begin{array}{c}33.26 \\
{[233.32]}\end{array}$ & 414 \\
\hline Ceremonies and religious expenses & $\begin{array}{c}8.47 \\
(11.37)\end{array}$ & $\begin{array}{c}9.40 \\
(11.29)\end{array}$ & $\begin{array}{c}35.50 \\
{[72.71]}\end{array}$ & 414 \\
\hline Panel B - Finance & & & & \\
\hline Amount saved (INR 1000s) & $\begin{array}{c}0.24 \\
(0.84)\end{array}$ & $\begin{array}{c}0.29 \\
(0.85)\end{array}$ & $\begin{array}{c}2.77 \\
{[6.66]}\end{array}$ & 409 \\
\hline Current formal amount borrowed (INR 1000s) & $\begin{array}{l}-0.22 \\
(2.21)\end{array}$ & $\begin{array}{l}-0.11 \\
(2.46)\end{array}$ & $\begin{array}{c}6.53 \\
{[28.41]}\end{array}$ & 414 \\
\hline Current informal amount borrowed (INR 1000s) & $\begin{array}{c}3.31 \\
(2.75)\end{array}$ & $\begin{array}{c}3.07 \\
(2.76)\end{array}$ & $\begin{array}{c}3.95 \\
{[12.85]}\end{array}$ & 414 \\
\hline $\mathrm{Nb}$ of current loans & $\begin{array}{l}-0.00 \\
(0.09)\end{array}$ & $\begin{array}{l}-0.01 \\
(0.09)\end{array}$ & $\begin{array}{c}0.53 \\
{[0.73]}\end{array}$ & 414 \\
\hline $\mathrm{Nb}$ of current informal loans & $\begin{array}{l}-0.04 \\
(0.07)\end{array}$ & $\begin{array}{l}-0.04 \\
(0.08)\end{array}$ & $\begin{array}{c}0.38 \\
{[0.62]}\end{array}$ & 414 \\
\hline
\end{tabular}

1. We report OLS regression coefficients with robust SE in ( ), standard deviations in [ ].

${ }^{*} p<0.10,{ }^{* *} p<0.05,{ }^{* * *} p<0.01$

2. The set of controls is individual indicator variables for whether participant is Muslim, Koshti caste or other Hindu castes (Padmasali caste omitted), whether participant was identified by referral, and whether a family member responded to the survey.

3. Temptation goods include alcohol, tea outside, movies, paan, cigarettes, bidis.

4. Expenditure questions exclude deceased and incapacitated participants, whose families were not asked these questions. The sample for alcohol expense excludes two outliers (1 winner) with expenses greater than 8 standard deviations above the mean. 
Appendix Table 5: Informal Insurance

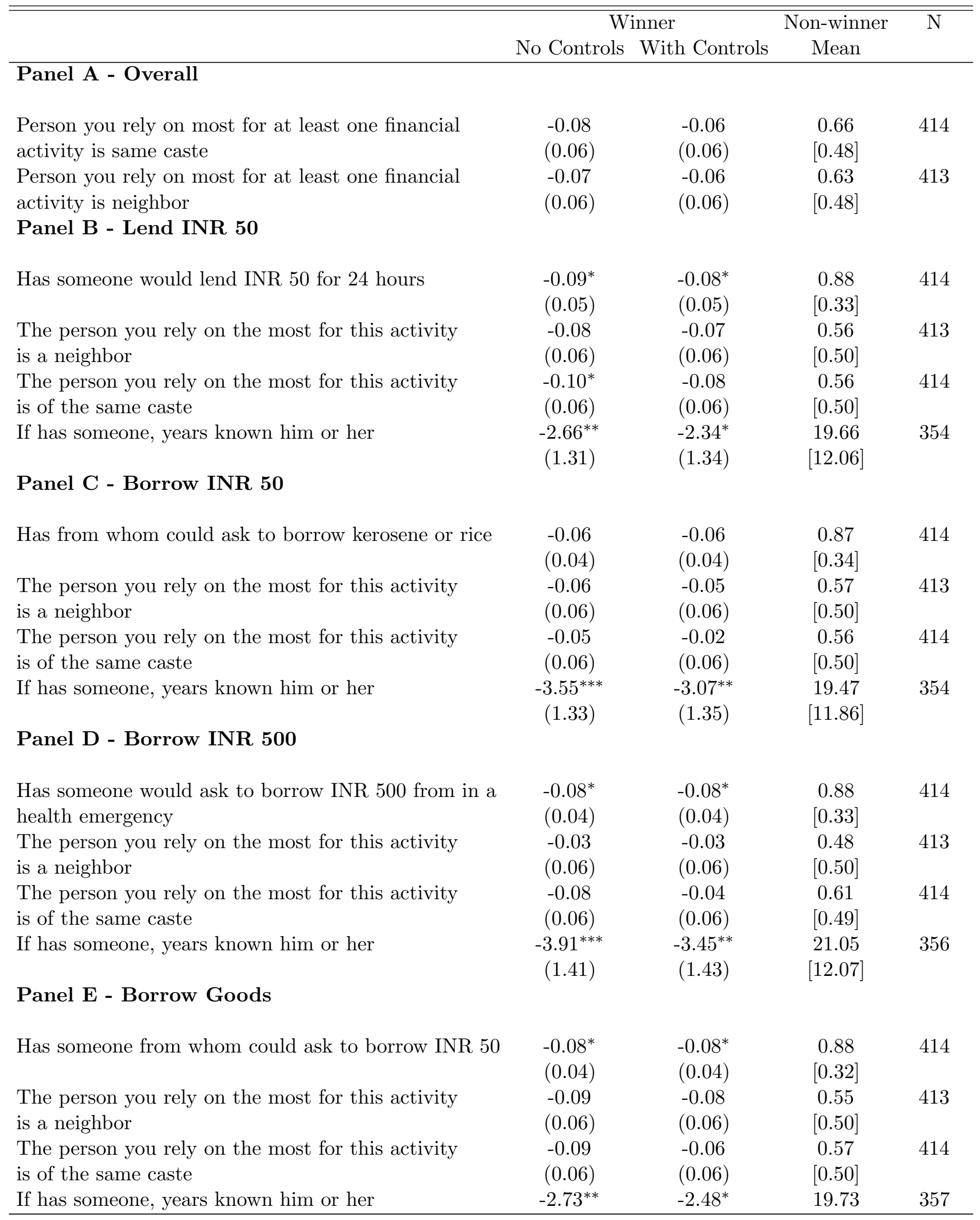




\section{Panel F - Shocks}

Experienced any of three large shocks

\begin{tabular}{cccc}
-0.00 & 0.01 & 0.96 & 434 \\
$(0.02)$ & $(0.02)$ & {$[0.19]$} & \\
-0.01 & 0.01 & 2.70 & 434 \\
$(0.08)$ & $(0.07)$ & {$[0.68]$} & \\
-3.80 & -1.31 & 28.13 & 424 \\
$(2.47)$ & $(2.27)$ & {$[22.48]$} & \\
$-0.06^{* *}$ & $-0.04^{*}$ & 0.09 & 403 \\
$(0.02)$ & $(0.02)$ & {$[0.29]$} & \\
\hline
\end{tabular}

shocks

$(0.02)$

$(0.02)$

1. We report OLS regressions with robust SE in ( ), standard deviations in [ ].

${ }^{*} p<0.10,{ }^{* *} p<0.05,{ }^{* * *} p<0.01$

2. The set of controls is individual indicator variables for whether participant is Muslim, Koshti caste or other Hindu castes (Padmasali caste omitted), whether participant was identified by referral, and whether a family member responded to the survey. 